\title{
1 Effect of surface texture and structure \\ 2 on the development of stable fluvial \\ 3 armors
}

4

5 Stephane Bertin and Heide Friedrich, Department of Civil and Environmental Engineering,

6 The University of Auckland, Auckland, New Zealand.

8 Corresponding author: S. Bertin, Department of Civil and Environmental Engineering, The

9 University of Auckland, Private Bag 92019, Auckland Mail Centre, Auckland 1142, New

10 Zealand. Email: s.bertin@ymail.com

12 Highlights:

13 - Gravel beds were measured through water using digital photogrammetry

- Gravel-beds' structure is more responsive than texture to discharge increases

- Spatial variability within armored beds is less than for screeded beds

- Armoring manifestations are replicable under identical formative parameters

- Relationships between armor properties and formative parameters are presented

\section{Abstract}

19 Stable fluvial armors are found in river systems under conditions of partial sediment transport

20 and limited sediment supply, a common occurrence in nature. Stable armoring is also readily

21 recreated in experimental flumes. Initially, this bed stabilizing phenomenon was examined for

22 different flow discharges and solely related to surface coarsening and bedload transport

23 reduction. The models developed suggest a specific armor composition (i.e., texture) dependent 
24 on the parent bed material and formative discharge. Following developments in topographic 25 remote sensing, recent research suggests that armor structure is an important control on bed

26 stability and roughness. In this paper, replicated flume runs during which digital elevation

27 models (DEMs) were collected from both exposed and flooded gravel beds are used to interpret 28 armoring manifestations and to assess their replicability. A range of methodologies was used 29 for the analysis, providing information on (i) surface grain size and orientation, (ii) bed30 elevation distributions, (iii) the spatial coherence of the elevations at the grain-scale, (iv) 31 surface slope and aspect, (v) grain imbrication and (vi) the spatial variability in DEM 32 properties. The bed-surface topography was found to be more responsive than bed-material 33 size to changes in flow strength. Our experimental results also provide convincing evidence 34 that gravel-beds' response to water-work during parallel degradation is unique (i.e., replicable) 35 given the formative parameters. Based on this finding, relationships between the armors' 36 properties and formative parameters are proposed, and are supported by adding extensive data 37 from previous research.

\section{Keywords}

39 Armoring; Gravel-bed roughness; Photogrammetry; DEM.

\section{Classification}

41 7000: Fluvial processes and landforms. 


\section{Introduction}

43 Stable fluvial armors commonly occur in poorly-sorted gravel-bed rivers during partial sediment transport (i.e., when the imposed bed shear stress is less than the critical shear stress required to initiate motion of all particles on the bed surface), with little to no sediment supply from upstream (Proffitt, 1980; Chin et al., 1994; Gomez, 1994; Vericat et al., 2006). The inherent stability-seeking mechanism for the formation of a stable armor is the preferential entrainment (winnowing) of fine mobile particles, uncovering coarse immobile particles forming a layer typically $\sim 1-2$ grain diameters thick, which isolates the underlying bed material from the flow to prevent further bed degradation (Parker and Klingeman, 1982; Gomez, 1983; Parker and Sutherland, 1990; Richards and Clifford, 1991; Gomez, 1993; Pitlick et al., 2008).

Stable armors hence form as a result of a progressive reduction in sediment transport to practically zero (Gessler, 1967). Stable armors are found downstream of dams and lakes. They also gradually develop in initial reaches of a channel in response to flow and sediment supply, and propagate downstream and activate the same transport reduction in the following reaches (Willets et al., 1988; Paris, 1992).

In the literature, stable armors are also referred to as static armors or pavement, in comparison to mobile or dynamic armors. For the latter, sediment supply from upstream allows for the progressive equalization between the bedload and the subarmor composition (Paris, 1992; Marion et al., 2003; Mao et al., 2011). Mobile armors typically persist over floods (Parker and Klingeman, 1982; Wilcock and DeTemple, 2005; Clayton and Pitlick, 2008), eroded grains being replaced by similar-sized grains originating from upstream reaches. In contrast, stable armors may only persist during floods of a lesser magnitude than the formative flow, as they can "break up" with subsequent riverbed incision during higher flows (Laronne and Carson, 1976; Proffitt, 1980; Gomez, 1983; Chin et al., 1994; Vericat et al., 2006). Armors are also known to (re-)form on the falling limb of a hydrograph, together with a reduction in 
sediment mobility (Hassan et al., 2006; Mao, 2012). When all particle sizes present on the bed are in motion, no armor can form (e.g., Chin et al., 1994) and the bed's response involves other mechanisms, such as a slope reduction.

In nature, full mobilization of surface grains in gravel-bed rivers is not a frequent event. For instance, field observations in Carnation Creek in Canada (Haschenburger and Wilcock, 2003 ) and the lower Ebro in Spain (Vericat et al., 2006) indicate full mobilization for floods with a 7-yr return period or more. Thus, large portions of gravel beds typically remain in the state of partial transport over long periods of time, allowing stable armors to form. This aligns with the assumption that a correct description of sediment transport in most gravel-bed rivers is that of low rates of bed material influx over an already structured bed (Church et al., 1998; Hassan and Church, 2000).

Besides a possible wide occurrence in nature, recreating stable armoring in the laboratory allows the study of bed-flow interactions and the evolution of a gravel streambed under simple experimental conditions (i.e., partial transport and no sediment feed). A recent review by Yager et al. (2015) shows how various feedback mechanisms such as flow turbulence, bed arrangement and sediment transport, are only possible to be studied through laboratory investigations, which in turn will help for our understanding of field processes. Through laboratory studies measuring textural changes for different flow strengths, predictive relationships have been developed and suggest a specific (hence replicable) armor composition, dependent on the parent-bed material and the formative discharge (e.g., Odgaard, 1984; Chin et al., 1994; Garde et al., 2006). This is an important finding, providing means to predict gravelbed texture given the formative parameters, with important implications also for bed roughness parameterization based on sediment size and use in flow resistance and sediment transport equations. However, surface coarsening and the accentuated hiding of fines by bigger particles

91 that protrude into the flow are primary manifestations of streambed armoring early in the 
92 degradation process (Church et al., 1998; Garde et al., 2006; Heays, 2012). To explain the progressive decline in transport characteristic of stable armors, research is evolving to consider not only texture but the actual surface structure (i.e., topography), since the latter offers new perspectives on bed stability and roughness (Lane, 2005; Hodge et al., 2013). For instance, it was hypothesized early that armor formation involves the slow and complete rearrangement of the bed-surface material (Gomez, 1994). This rearrangement can manifest itself through structural changes, e.g., particle imbrication and interlocking (Laronne and Carson, 1976), the formation of small bedforms such as clusters (Chin et al., 1994; Heays et al., 2014) and reticulate stone cells (Church et al., 1998; Hassan and Church, 2000), which increase bed stability.

102 Recently, the collection and processing of alluvial bed-elevation data at high spatial and temporal resolutions have considerably grown the options to monitor riverbed structures and their adjustments to various flows (Coleman et al., 2011). Analysis of gravel-bed armors using digital elevation models (DEMs) can provide useful information on grain packing, orientation and imbrication, as well as on horizontal and vertical measures of bed roughness at the scales considered (e.g., Nikora et al., 1998; Aberle and Nikora, 2006; Millane et al., 2006; Cooper and Tait, 2009; Qin et al., 2012; Qin et al., 2013; Bertin and Friedrich, 2014). This proved pivotal in understanding the changes in sediment mobility and flow hydraulics due to the armor

110 layer, when traditional surface sampling methods failed (Marion et al., 2003; Cooper et al., 111 2008; Hodge et al., 2009; Mao et al., 2011; Hodge et al., 2013). Likewise, some workers found 112 the standard deviation of bed elevations $\left(\sigma_{\mathrm{Z}}\right)$ to be a robust measure of effective bed roughness 113 in flow resistance equations (e.g., Smart et al., 2002). Other flume studies showed that gravel-

114 bed topography is indicative of the flows that shaped the surface (e.g., Aberle and Nikora, 115 2006; Powell et al., 2016), with typical manifestations such as increasing roughness, decreasing 116 bed-surface complexity and flourishing bedforms with increasing flow discharge. Ockelford 
117 and Haynes (2013) proved that sub-threshold flows also are able to change bed structure,

118 mainly by re-orientating unstable grains. It has also become clear that fluvial surfaces are

119 regulated by the parent-bed material, sediment shape (Gomez, 1994), and by the amount of 120 sand in the mixture (Curran and Tan, 2014). Summarizing these findings, comparisons between

121 some armor structural properties and formative parameters have been presented (e.g., Mao et 122 al., 2011; Powell et al., 2016). However, whilst previous research recognized the strong correlation between armor structure (e.g., $\sigma \mathrm{z}$ ) and bed composition (see Pearson et al., 2017 for a summary of the different relationships), it did not make conclusions on the replicability in surface structure. Particularly, Aberle and Nikora (2006) reported differences in armor properties after replicating one of their flume tests, thus casting doubts on the uniqueness of the bed response to a given parent bed material and formative discharge.

In this paper, we use a series of replicated flume experiments to determine stable armor manifestations, extending the range of surface metrics representing texture and structure compared to previous work, and to assess their replicability. Previous studies investigated armor properties for different flow and sediment conditions (Gomez, 1993; Chin et al., 1994;

132 Gomez, 1994; Church et al., 1998; Aberle and Nikora, 2006; Garde et al., 2006; Cooper and Tait, 2009; Mao et al., 2011; Ockelford and Haynes, 2013). Other works studied the changes during the armoring process itself (Hassan and Church, 2000; Marion et al., 2003; Heays et al., 2014; Powell et al., 2016). Here we examine the extent to which fluvial armors are replicable under identical flow and parent sediment bed conditions, in other words, is there a specific relationship between the armor properties and the flow and sediment forming them? To answer this question, we present new insights on the spatial variability within water-worked gravel beds. We also examine the connections between armor properties and formative parameters, and compare our results with extensive data from previous research. 


\section{Experimental methodology}

142 The armored beds examined in this study were formed in a laboratory flume using sediments

143 mixed from natural river-worn sands and gravels. Six replicated runs were performed, during

144 which an initially screeded flat and poorly-sorted gravel bed was water-worked successively

145 with two discharges until stable armors were formed, in condition of parallel degradation (i.e.,

146 no sediment feed and selective entrainment). Bedload reduction during armoring was thus a

147 result of textural and structural changes at the bed surface, rather than a shear stress reduction

148 due to decreasing bed slope. For each test, bedload rate and composition were measured during

149 the degradation process; bed texture and structure were determined prior and after armor

150 formation. To assess the replicability of our experiments, each experimental run was set up

151 identically and flow conditions were kept as constant as possible within and between runs.

152 Water temperature, discharge, shear velocity, and bed levels were monitored throughout each

153 run, with adjustments made when necessary. In particular, the condition of a constant bed shear

154 stress despite bed degradation was justified by raising the sediment bed according to the depth

155 of erosion, to maintain bed and water surface slopes steady, a technique successfully used

156 previously (e.g., Chin et al., 1994; Heays et al., 2014).

\section{2.1. Experimental environment}

158 The experiments were conducted in a non-recirculating tilting flume with glass side-walls, 19

$159 \mathrm{~m}$ long, $0.45 \mathrm{~m}$ wide and $0.5 \mathrm{~m}$ deep, shown in Fig. 1. A $0.95 \mathrm{~m}$ long, $0.45 \mathrm{~m}$ wide and $0.13 \mathrm{~m}$

160 deep sediment recess (called the test section), with a vertically adjustable table that supported

161 the movable sediment bed, was installed $10.4 \mathrm{~m}$ from the flume inlet. To facilitate the

162 development of a fully turbulent boundary layer and homogeneous hydraulic conditions, the

163 approach bed was roughened by an attached single-particle-thick layer of gravel, simulating

164 the roughness of an armored bed; the flume bed downstream of the test section was coated with 
an exact replicate (plastic mold) of a stable armor obtained at the Leichtweiss-Institute for

166 Hydraulic Engineering in Braunschweig, Germany (Spiller et al., 2012), with a texture and

167 structure resembling (parent bed $\mathrm{D}_{50}=5 \mathrm{~mm}, \mathrm{D}_{100}=31.5 \mathrm{~mm}$, and $\sigma_{Z}=4.9 \mathrm{~mm}$ ) the stable

168 armors formed in our experiments. Outside the plastic mold, a $0.2 \mathrm{~m}$ long full-width sediment

169 trap with a $0.2 \mathrm{~mm}$ mesh was added $0.5 \mathrm{~m}$ downstream of the test section and allowed collection

170 of all eroded sediment (see Supporting Information on bedload trap). Otherwise, the setup is

171 identical to the one used by Chin et al. (1994) in their seminal work on streambed armoring.

172 During the runs, the flume was operated in an open-circuit manner using the laboratory

173 water supply, with the flow being delivered through a $0.25 \mathrm{~m}$ diameter pipe from the constant

174 head reservoir, giving a maximum discharge of $100 \mathrm{~L} / \mathrm{s}$. Water entered the flume through a

175 flow straightener, and returned through floor channels and a calibrated pit to a sump for reuse.

176 The flow rate was measured using an orifice plate and a differential manometer. The calibration

177 of the orifice plate was checked using the laboratory calibrated pit that enables flow

178 measurement to better than 1\% accuracy (Heays et al., 2014).

179

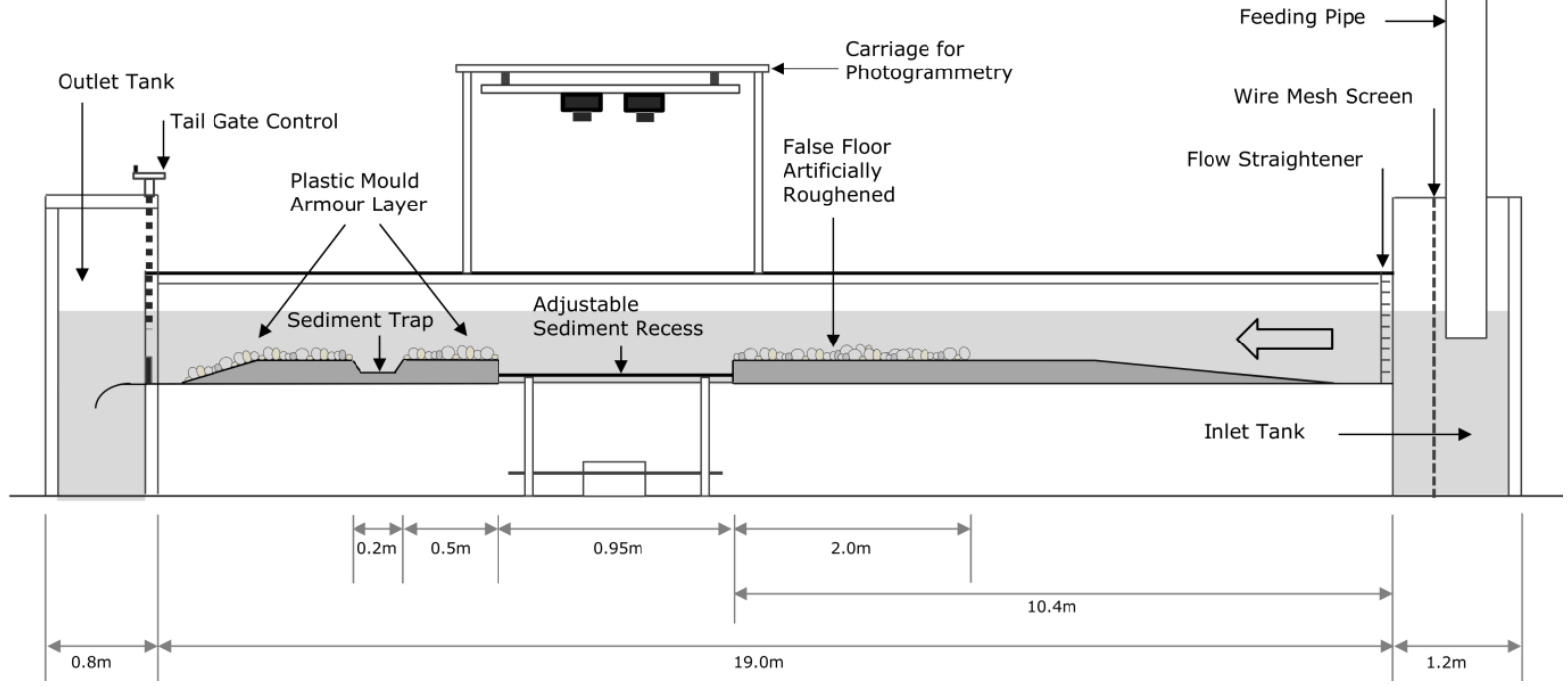

180 Fig. 1. Experimental setup. 
182 Two coarse and poorly-sorted sediment mixtures, called sediment 1 and sediment 2 , were

183 prepared from two distinct, slightly bimodal, alluvial sediments (15\% sand and $85 \%$ gravel, 184 and 9\% sand and 91\% gravel, respectively), with sizes ranging from 0.7 to $35 \mathrm{~mm}$, and used as 185 movable bed materials for the development of stable armors in the sediment recess. The 186 sediment grading curves shown in Fig. 2 were obtained by sieving large samples $(21.5 \mathrm{~kg}$ and

$18717 \mathrm{~kg}$ for sediment 1 and 2, respectively), and a correction procedure (Church et al., 1987) 188 accounted for the used square-hole sieves. Median grain size, $\mathrm{D}_{50}$, was $8.4 \mathrm{~mm}$ and $9.2 \mathrm{~mm}$ 189 and the sediment geometric sorting, $\sigma_{\mathrm{g}}$, was 3.0 and 2.6, for sediment 1 and sediment 2, respectively. Sediment shape and specific gravity were also determined (cf. Table 1). Both sediment mixtures were described as disc-shaped according to Zingg's classification. However, sediment 1 was more compact and lighter, which together with having smaller grains, was thus 193 potentially easier to entrain for a similar flow, than sediment 2 (Fig. 2B).

A

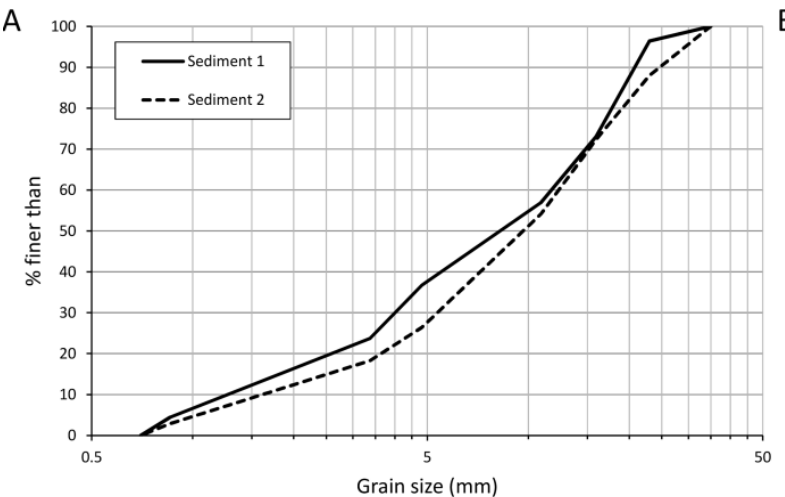

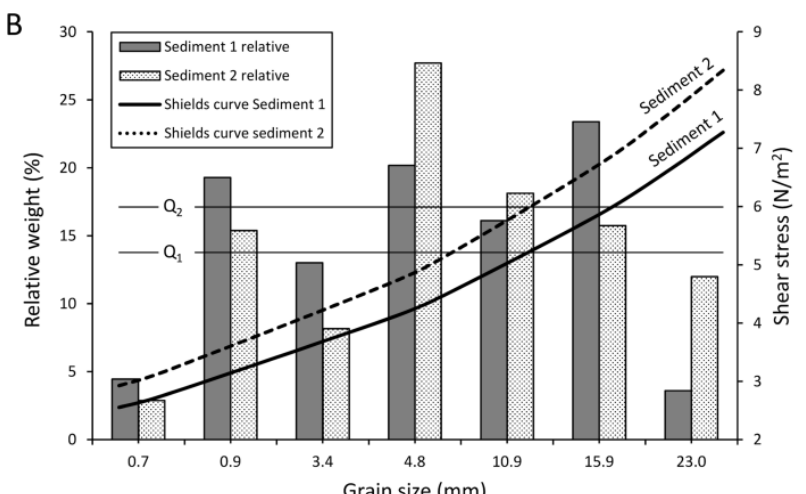

195 Fig. 2. Grain-size distributions (GSDs) obtained after sieving and correcting for the square-hole sieves

196 and size fraction mobility using the Shields curve modified for different hiding/exposure (see

197 Supporting Information on flow competence analysis). 
198 Table 1. Experimental sediment mixtures prepared from two distinct alluvial sediments.

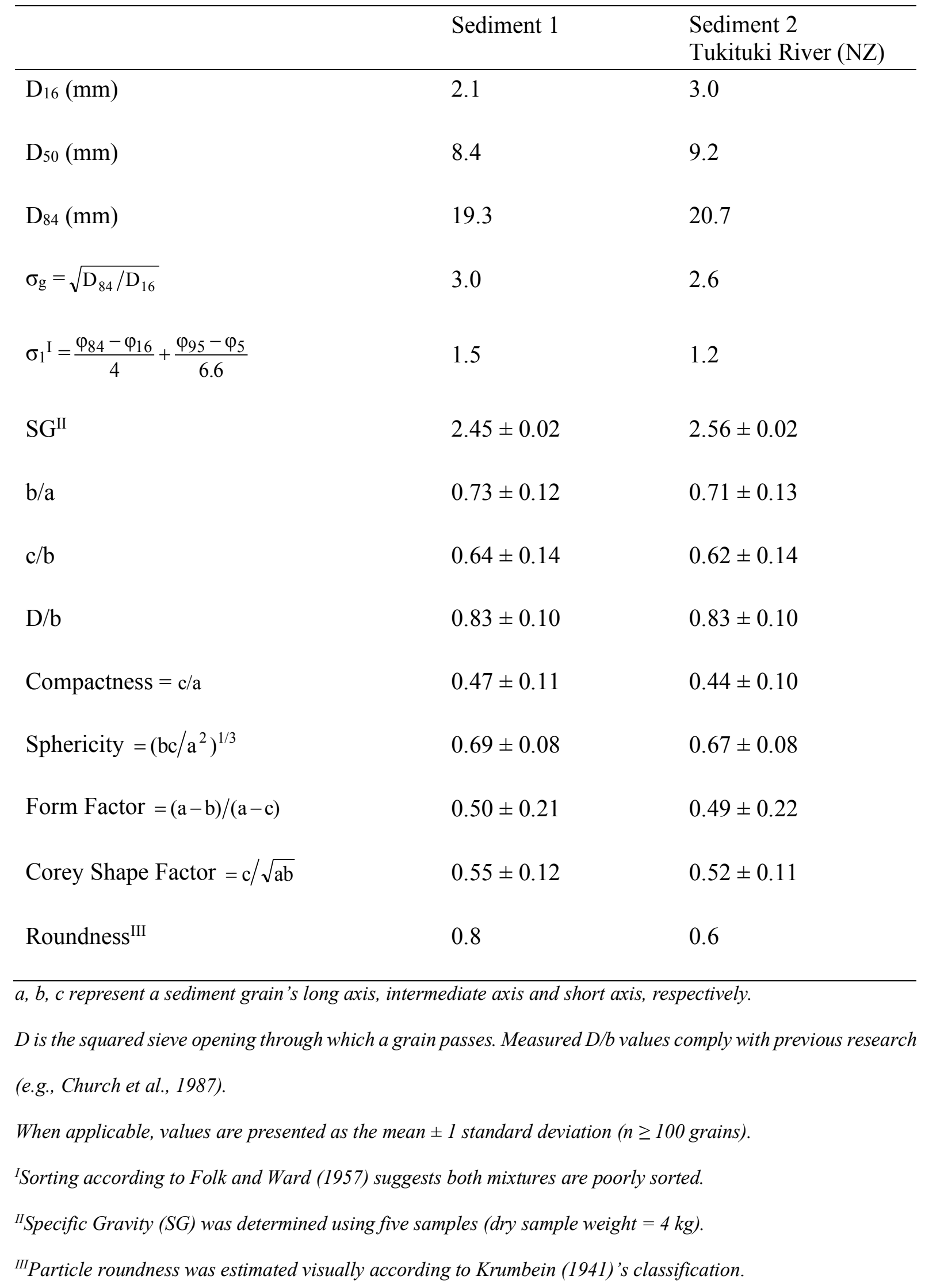


207 At the beginning of a run, the well-mixed sediment was placed in the test section, screeded flat

208 to a thickness of $0.13 \mathrm{~m}$, parallel to the flume bed, and leveled with the surrounding fixed beds.

209 The flume slope was held constant at $0.5 \%$.

210 After a short period of low flow, allowing the air trapped in the gravel to escape, a constant

211 flow discharge $\mathrm{Q}_{1}=67 \mathrm{~L} / \mathrm{s}$ (mean flow velocity $\overline{\mathrm{U}}=0.75 \mathrm{~m} / \mathrm{s}$, shear velocity $\mathrm{u}^{*}=0.072 \mathrm{~m} / \mathrm{s}$

212 and water depth $\mathrm{H}=0.195 \mathrm{~m}$ ) was applied over $100 \mathrm{~h}$. The flume tail gate was set at the same

213 height as the sediment bed to allow the water depth to naturally adjust, while near uniform flow

214 conditions were attained (cf. Table 2). A constant flow rate $\mathrm{Q}_{2}=84 \mathrm{~L} / \mathrm{s}\left(\overline{\mathrm{U}}=0.82 \mathrm{~m} / \mathrm{s}, \mathrm{u}^{*}=\right.$

$2150.077 \mathrm{~m} / \mathrm{s}$ and $\mathrm{H}=0.225 \mathrm{~m}$ ) was then applied during $300 \mathrm{~h}$ on the previously formed stable

216 armor generated under discharge $\mathrm{Q}_{1}$. To justify the condition of a constant bed shear stress

217 during parallel degradation, the sediment-recess table was manually adjusted upwards with

218 screw jacks according to the rate of erosion in the test section (cf. Chin et al., 1994). This way,

219 the overall bed and water surface slopes remained constant and parallel throughout the

220 degradation process. In practice, the test section was adjusted minimally but constantly at the

221 beginning of each armoring phase (especially with $\mathrm{Q}_{1}$ ), during the first 5 to $10 \mathrm{~h}$, until the depth

222 of erosion plateaued. Confirmed by our measurements, no effect on transport rate due to

223 adjusting the test section was observed. The flow was stopped when sediment transport

224 dropped to less than $1 \%$ of the initial rate (here the transport rate after two hours at a constant

225 discharge). The same criterion for defining a stable armor was used previously by others (e.g.,

226 Proffitt, 1980; Gomez, 1993; Hassan and Church, 2000; Mao et al., 2011; Curran and Waters,

227 2014). Likewise, a pilot test was used to determine the stopping times for $\mathrm{Q}_{1}$ and $\mathrm{Q}_{2}$, assuming

228 this would hold for replicated tests (e.g., Church et al., 1998; Powell et al., 2016). 
229 Table 2. Flow conditions for the formation of the two successive stable armors.

\begin{tabular}{|c|c|c|c|c|c|c|c|}
\hline & $\mathrm{H}(\mathrm{m})$ & $\overline{\mathrm{U}}(\mathrm{m} / \mathrm{s})$ & $\mathrm{Re}$ & $\mathrm{u}^{*}(\mathrm{~m} / \mathrm{s})$ & $\tau *$ & $\mathrm{Re}^{*}$ & Duration (h) \\
\hline $\mathrm{Q}_{1}=67 \mathrm{~L} / \mathrm{s}$ & 0.195 & 0.75 & 79,300 & $0.0722^{I}$ & $\begin{array}{l}0.044^{1} \\
0.040^{2}\end{array}$ & $513^{\mathrm{II}}$ & 100 \\
\hline $\mathrm{Q}_{2}=84 \mathrm{~L} / \mathrm{s}$ & 0.225 & 0.82 & 92,800 & $0.0774^{\mathrm{I}}$ & $\begin{array}{l}0.050^{1} \\
0.046^{2}\end{array}$ & $526^{\mathrm{II}}$ & 300 \\
\hline
\end{tabular}

H is flow depth; $\overline{\mathrm{U}}$ is flow depth-averaged velocity; $R e=\overline{\mathrm{U}} R_{h} / \nu$, where $R_{h}$ is the hydraulic radius and $v$ is the

231 kinematic viscosity of water (taken as $10^{-6} \mathrm{~m}^{2} / \mathrm{s}$ ); $\tau *$ is Shields stress based on the parent bed $D_{50}$, calculated as

$232 u^{* 2} /(S G-1) g D_{50}$; and $R^{*}=u^{*} k_{s} / \nu$ is the grain Reynolds number.

$233{ }^{1,2}$ is for the two different sediment mixtures (Table 1). Low transport rates characterized the study.

$234{ }^{I}$ The shear velocity $u^{*}$ and the equivalent roughness height $k_{s}$ were estimated from the law-of-the-wall and a velocity profile measured in the centerline of the flume over the fixed roughness bed upstream of the test section, using a Vectrino + acoustic velocimeter (Nortek $®)$, with $200 \mathrm{~Hz}$ sampling rate and $120 \mathrm{~s}$ sampling time. Fifteen measurement points along the lower $75 \%$ of the water column were recorded (with five points along the lowest $10 \mathrm{~mm}$ ). WinADV® was used to remove spikes (using the phase-space threshold despiking method) and data with low correlation (minimum COR > 70) and/or low signal-to-noise ratio (minimum SNR > 15). Typically, most of

240 the velocity profile, with the exception of the region very close to the bed (lowest $10 \mathrm{~mm}$ ), exhibited a semilogarithmic velocity distribution. Measured $u^{*}$ values comply with calculations assuming uniform flow (i.e.,

242 depth-slope product).

${ }^{I I}$ Values of Re* indicate fully-rough turbulent flows.

\subsection{Bedload rate and composition}

245 The material collected in the sediment trap was sampled throughout the runs to monitor the 246 changes in bedload with armoring time, and to assess the process replicability. Keeping the 247 sampling interval constant was often not feasible due to time and personnel availability 248 constraints. When possible, it was preferred to wait until a "significant" quantity (aim was bedload material $\geq 0.5 \mathrm{~kg}$ ) was trapped, enabling more robust calculation of the bedload 
composition. The same sampling and analysis procedure as the initial sediment mixtures was followed, enabling comparison of bedload and parent bed (i.e., bulk mixture) compositions.

\subsection{Bed surface measurement}

253 A pair of Nikon D5100 cameras (16.4 Mpixel, $23.6 \times 15.6 \mathrm{~mm}^{2}$ sensor size) with Nikkor 20 $\mathrm{mm}$ lenses, placed $0.3 \mathrm{~m}$ apart using a mounting bar, was installed $0.65 \mathrm{~m}$ vertically above the test section (Fig. 1) to allow the accurate measurement of bed texture and structure with digital photogrammetry.

Using a single photograph (area: $0.65 \times 0.35 \mathrm{~m}^{2}$, pixel size: $0.15 \mathrm{~mm}$, number of detected sediment grains $\sim 1000$ ), armor composition and gravel orientation were determined with the image-analysis tool Basegrain ${ }^{\circledR}$, which allows for automatic grain separation in digital images of gravel beds and applies the Fehr's (1987) line-sampling method for the results' analysis (Detert and Weitbrecht, 2012). To easily distinguish grain-size properties of the armors from those of the bulk mixtures, the former were indexed with "A". As is common practice (e.g., Aberle and Nikora, 2006; Mao et al., 2011), the composition of the screeded beds was assumed equal to the bulk mixtures' composition (Fig. 2). Photographs of the armors after waterworking with $\mathrm{Q}_{1}$ were obtained through water $(\mathrm{H}=0.13 \mathrm{~m})$, to avoid draining and re-filling the flume (see Supporting Information on grain-size distribution characterization and validation). In addition to the armor composition, Basegrain ${ }^{\circledR}$ reported the detected grains' aaxis orientation, which was determined by fitting an ellipse whose areal normalized secondcentral moment equals that of the grain and computing the angle formed between the ellipse long axis and the flow-orientated image long axis.

At all stages in the experiment (i.e., at the screeded stage and after armoring), highresolution DEMs of the gravel-bed surface (area: $0.95 \times 0.45 \mathrm{~m}^{2}$, grid spacing: $1 \mathrm{~mm}$,

273 theoretical depth resolution: $0.35 \mathrm{~mm}$ ) were reconstructed from three overlapping stereo 274 photographs (i.e., six images) using the technique presented in Bertin et al. (2015). A brief 
description is given hereafter. Necessary camera calibration was performed in-situ at the beginning of a test using a flat chequerboard, before the recess was loaded with sediment, to

277 allow subsequent measurements of gravel-bed topography both in air and through water (see

278 Supporting Information on camera calibration). Using the calibration data, gravel-bed stereo

279 images were rectified to epipolar geometry, corresponding pixels being ideally on a same 280 scanline, before scanline-based pixel-to-pixel stereo-matching using the symmetric dynamic 281 programming stereo (SDPS) algorithm (Gimel'farb, 2002). During stereo-matching, depth is 282 triangulated at each pixel location (pixel size $\sim 0.15 \mathrm{~mm}$ ), and occluded (i.e., shadowed) points are interpolated based on the assumption of a continuous surface, leaving no voids in the point clouds. Point clouds were filtered to remove possible outliers (filtered points represented strictly less than $1 \%$ of the initial data, and were replaced using interpolation) before resampling on a $1 \mathrm{~mm}$ grid (see Supporting Information on DEM validation). Before analysis, the DEMs were resized to $0.8 \times 0.3 \mathrm{~m}^{2}$ to minimize flume wall influence. Similar to previous research, DEMs were detrended to remove any surface trend that could bias the grainroughness properties of interest (e.g., Aberle and Nikora, 2006; Hodge et al., 2009). First, linear trend surfaces representing the combined effect of flume-bed slope and setup misalignment

291 (when the cameras are not perfectly set parallel to the flume bed, causing a tilt in the DEM) were removed from the data using a least-squares fit procedure. Second, any low-amplitude bedform on the gravel-bed surface, larger than particle clusters, was also removed, through the application of a moving filter of radius $1_{1.25 D_{90 A}}$ (Smart et al., 2002). DEMs were finally normalized and rotated to have a zero-mean bed elevation and increasing x-values with the flow direction.

\section{6. $\quad$ Analytical methods}

298 Bed structure was defined using a large range of parameters, all of which were previously 299 invented but rarely used in unison. Parameter comparisons between armors formed at different 
discharges and/or with different sediments, allowing general armoring manifestations as well as differences between armors due to varying the formative parameters to be identified, were consistently performed using the Student's t-test.

For all experimental runs, detrended DEMs were first analyzed in terms of standard deviation $\left(\sigma_{\mathrm{Z}}\right)$, range $\left(\Delta_{\mathrm{Z}}\right)$ and skewness $\left(\mathrm{S}_{\mathrm{K}}\right)$. The latter are bed-elevation moments contained in probability distribution functions (PDFs) and classical descriptors of bed roughness.

Generalized second-order structure functions of detrended bed elevations were also obtained to study correlations in bed elevations at the grain scale (hence representing characteristics of grain size, shape and 2D arrangement on the bed surface). This analysis method, which is often used for gravel-bed river research, is of the same family as semivariograms or autocorrelation functions (Robert and Richards, 1988; Bergeron, 1996;

311 Butler et al., 2001; Marion et al., 2003), and is defined by Nikora et al. (1998) in discrete form as:

$$
D_{G 2}(\Delta x, \Delta y)=\frac{1}{(N-n)(M-m)} \sum_{i=0}^{N-n} \sum_{j=0}^{M-m}\left\{z\left(x_{i}+n \delta x, y_{j}+m \delta y\right)-z\left(x_{i}, y_{j}\right)\right\}^{2}
$$

314 where, $\Delta \mathrm{x}=\mathrm{n} \delta \mathrm{x}$ and $\Delta \mathrm{y}=\mathrm{m} \delta \mathrm{y}$ are the spatial lags (maximum set at $\pm 100 \mathrm{~mm}$ ); $\delta \mathrm{x}$ and $\delta \mathrm{y}$ are

315 the sampling intervals (both $1 \mathrm{~mm}$ ) in the longitudinal and transverse directions respectively;

$316 \mathrm{n}=1,2,3, \ldots \mathrm{N}$ and $\mathrm{m}=1,2,3, \ldots \mathrm{M} . \mathrm{N}$ and $\mathrm{M}$ are the number of samples $(801$ and 301 ,

317 respectively) in the same two directions. Following Nikora et al. (1998), we determined the 318 directional Hurst exponents $\mathrm{H}_{\mathrm{X}}$ and $\mathrm{H}_{Y}$, representing a basic method to examine the degree of 319 bed complexity/irregularity along the downstream and transverse directions, respectively, as 320 well as the horizontal (grain-) roughness indices $\Delta \mathrm{X}_{0}$ and $\Delta \mathrm{Y}_{0}$, representing the correlation 321 lengths of the detrended bed elevations.

Slope and aspect angles of each of the $1 \mathrm{~mm}^{2}$ detrended DEM grid cells, measuring 3D grain arrangement, were determined following the method presented in Hodge et al. (2009). 
324 Cell slope and aspect are calculated using a 3-by-3 moving window, in which the gradients of

325 the center cell (with elevation $\mathrm{Z}_{\mathrm{xy}}$ ) in the $\mathrm{x}$-direction and $\mathrm{y}$-direction are calculated as:

$$
\frac{d z}{d x}=\left[\left(Z_{x-1 y+1}+2 Z_{x-1 y}+Z_{x-1 y-1}\right)-\left(Z_{x+1 y+1}+2 Z_{x+1 y}+Z_{x+1 y-1}\right)\right] / 8 c
$$

$$
\frac{d z}{d y}=\left[\left(Z_{x-1 y+1}+2 Z_{x y+1}+Z_{x+1 y+1}\right)-\left(Z_{x-1 y-1}+2 Z_{x y-1}+Z_{x+1 y-1}\right)\right] / 8 c
$$

where $Z_{x-1 y-1}$ through to $Z_{x+1 y+1}$ are the elevations of the eight perimeter cells and $c$ is the cell width (i.e., $1 \mathrm{~mm})$. The cell slope (S) is calculated from:

$$
S=\arctan \sqrt{\left(\frac{d z}{d x}\right)^{2}+\left(\frac{d z}{d y}\right)^{2}}
$$

and the cell aspect (A) from:

$$
A=\arctan \left(\frac{d z}{d x} / \frac{d z}{d y}\right)
$$

with $\mathrm{A}=\mathrm{A}+180^{\circ}$ in the case that $\mathrm{dz} / \mathrm{dx}<0$. A was further re-arranged to have cells with a zero aspect angle facing upstream.

Furthermore, the inclination index (I) was evaluated. The inclination index measures grain imbrication, by analyzing the signs of elevation changes between successive pairs of detrended DEM points at different lags, in different directions (Millane et al., 2006):

$$
\mathrm{I}(\mathrm{d}, \theta)=\frac{\mathrm{n}_{+}(\mathrm{d}, \theta)-\mathrm{n}_{-}(\mathrm{d}, \theta)}{\mathrm{N}(\mathrm{d}, \theta)}
$$

where $n_{+}$and $n_{-}$are the number of positive (here defined as increasing elevations along the flow direction) and negative slopes, respectively, and $\mathrm{N}$ is the total number of slopes, all functions of the separation or lag $\mathrm{d}$ between pairs of DEM points and the angle $\theta$ formed with the flow direction. Inclination indices were computed using $\mathrm{d}=1 \mathrm{~mm}$, which is the DEM grid spacing,

343 the lag for which imbrication was the most perceptible. Slopes, whose absolute value was

344 below 0.01 , were deemed not reliable, and were not counted in the numerator of Eq. (6)

345 (Millane et al., 2006). A positive inclination index reflects the dominance of positive slopes 
and thus particle imbrication, which should be maximum in the flow direction, minimum in the

347 direction opposite to the flow, and approximately zero in a direction transverse to the flow

348 (Millane et al., 2006). We thus focused the analysis on $\mathrm{I}\left(0^{\circ}\right)$, the inclination index measuring 349 grain imbrication in the flow direction.

350 To test the hypothesis that stable armors are replicable under identical flow and sediment conditions, we compared the variability between repeat runs with the spatial variability naturally present within gravel beds, in terms of the different DEM properties measured ((i) $\mathrm{S}_{\mathrm{K}}$, (ii) $\sigma_{\mathrm{Z}}$, (iii) $\mathrm{H}_{\mathrm{X}}$ and $\mathrm{H}_{\mathrm{Y}}$, (iv) $\Delta \mathrm{X}_{0}$ and $\Delta \mathrm{Y}_{0}$ and (v) $\mathrm{I}\left(0^{\circ}\right)$ ). This analysis was made possible by the large DEM size $\left(800 \times 300 \mathrm{~mm}^{2}\right)$. Previous studies generally restrained DEM analysis to smaller surfaces, for example ranging from $117 \times 100 \mathrm{~mm}^{2}$ to $300 \times 250 \mathrm{~mm}^{2}$ due to measurement limitations when elevation is measured point-by-point or per transects, such as when using a laser displacement meter (e.g., Marion et al., 2003; Cooper and Tait, 2009; Mao et al., 2011; Ockelford and Haynes, 2013). To accurately capture the bed structure at the grain scale, Ockelford and Haynes (2013) used a square DEM size of 21 times the size of the mixture $\mathrm{D}_{50}$ in both directions. With a maximum $\mathrm{D}_{50}$ of $9.2 \mathrm{~mm}$ in our tests, this required DEMs of size at least $200 \times 200 \mathrm{~mm}^{2}$. Hence, for measuring the spatial variability within a gravel bed, each detrended DEM was divided in three sections of size $266 \times 300 \mathrm{~mm}^{2}$ and the coefficient of variation $(\mathrm{CV})$ was calculated as the standard deviation of the DEM property divided by the mean, and reported as a percentage, using the three DEM subsets. As replicated surfaces would imply, we found that DEMs of the same sediment and surface type (e.g., all three armors

366 formed with sediment 1 at the discharge $\mathrm{Q}_{1}$ ) were characterized by the same spatial variability.

367 Hence, the CV was averaged using the three repeat runs, providing the average spatial variability within gravel beds of the same sediment and surface type, for the different DEM properties. For both sediment mixtures, the variability between the three repeat runs was also measured using the $\mathrm{CV}$, at the screeded stage, after $\mathrm{Q}_{1}$ and after $\mathrm{Q}_{2}$. For all DEM properties, 
we thus (1) compared the variability between repeat runs using the same sediment mixture and the average spatial variability within these same DEMs; (2) concurrently, a MATLAB ${ }^{\circledR}$ routine was used to ensure no significant difference on the mean (i.e., average) values determined using

374 the three subsets of any replicated surface, using paired t-tests at a confidence level $\alpha=0.01$.

375 The observation of a similar variability (1) together with no significant difference on the mean

376 (2) would lead to the conclusion that experimentally replicated surfaces cannot be 377 distinguished.

\section{Experimental results}

379 In this section, we first examine the ensemble of armor manifestations observed using our dataset and methods, before testing our hypothesis of armor replicability. Interpretation of the findings and comparison with other research are presented in the discussion section.

\subsection{Bedload rate and composition}

383 For all experimental runs, the transport reduction with armoring time (Fig. 3) was well described by a relationship of the form $\mathrm{q}_{\mathrm{s}}=\mathrm{c} \cdot \mathrm{t}^{\mathrm{n}}$ (with $\mathrm{c}$ and $\mathrm{n}$ constants), which is characteristic of static armoring (Proffitt, 1980; Marion et al., 2003). The constants were the same regardless of the sediment mixture, however, different values were observed for $\mathrm{Q}_{1}$ and

387 Q2, showing distinct trends in transport reduction. For an initially screeded flat (unworked) gravel bed, exposed to a flow rate of $\mathrm{Q}_{1}=67 \mathrm{~L} / \mathrm{s}$, the transport rate rapidly dropped exponentially (Fig. 3a). Typically, about $60 \%$ of the sediment transported during $\mathrm{Q}_{1}$ was removed from the bed in the first hour. At the flow rate of $\mathrm{Q}_{2}=84 \mathrm{~L} / \mathrm{s}$ on a bed previously armored with $\mathrm{Q}_{1}$ (Fig. $\left.3 \mathrm{~b}\right)$, the initial transport rate $(\sim 0.1 \mathrm{~kg} / \mathrm{h})$ was much smaller than the value

392 observed during $\mathrm{Q}_{1}$ at the same epoch $(\sim 1.4 \mathrm{~kg} / \mathrm{h})$. During $\mathrm{Q}_{2}$, coarse particles composing the surface were entrained erratically (possibly due to turbulence bursts at the bed), leaving fines 

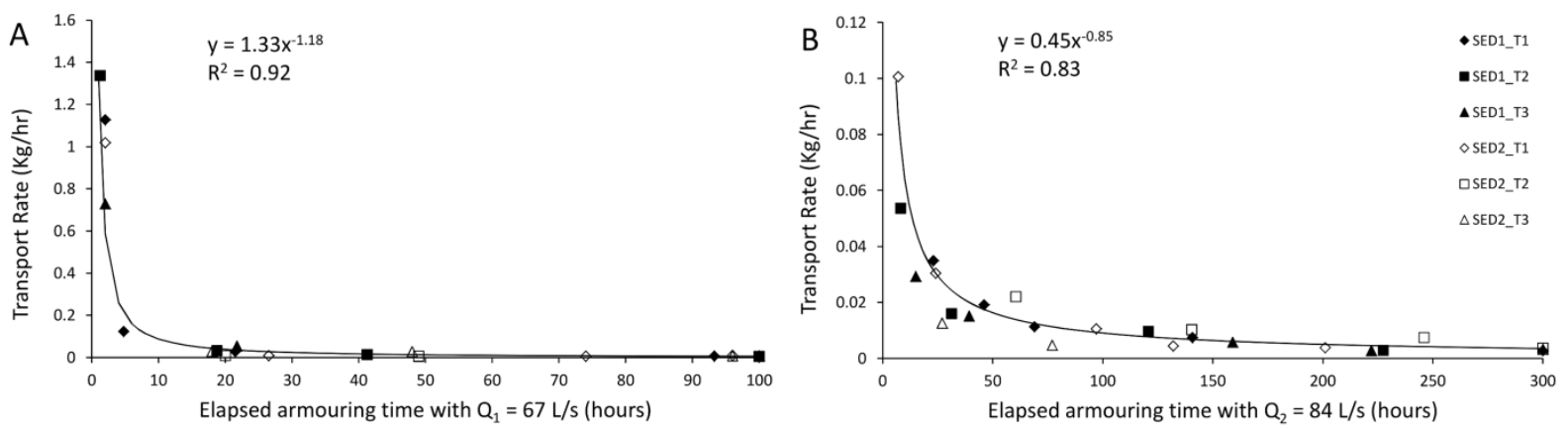

Fig. 3. Sediment transport at the sediment trap for all replicated runs during (A) armoring with $\mathrm{Q}_{1}$ on the initially screeded flat (unworked) gravel-beds; and (B) armoring with $\mathrm{Q}_{2}$ on the beds previously armored with $\mathrm{Q}_{1}$. Stable armors (i.e., final transport rate less than $1 \%$ of the initial rate) were completed in $100 \mathrm{~h}$ (approx. 4 days) and $300 \mathrm{~h}$ (approx. 12.5 days), for $\mathrm{Q}_{1}$ and $\mathrm{Q}_{2}$ respectively.

At the beginning of a run with sediment 1, the bedload composition (Fig. 4A) was much finer than the bulk mixture composition (e.g., bedload $\mathrm{D}_{50}$ less than half the mixture $\mathrm{D}_{50}$ ). As the surface coarsened, bedload size slowly increased and sometimes equaled the bulk mixture characteristics. This observation resembles the equalizing mechanism whereby stable armors act to nearly equalize sediment mobility (Parker and Klingeman, 1982; Parker and Sutherland, 1990), by exposing proportionally more coarse grains to the flow. A maximum bedload size was reached, generally corresponding to the time of armor completion with $\mathrm{Q}_{1}$ or soon after the flow rate was changed to $\mathrm{Q}_{2}$. Bedload composition remained constant during armoring with Q2. For sediment 2 (Fig. 4B), a steady bedload composition was observed throughout the

411 formation of the two stable armors; the only notable exception being an increase in the bedload

$412 \mathrm{D}_{84}$ during $\mathrm{Q}_{2}$, indicating coarser grains were transported compared to $\mathrm{Q}_{1}$, due to the increased

413 discharge. Compared with sediment 1, the bedload composition for sediment 2 matched more 414 closely the bulk mixture composition, especially in terms of $\mathrm{D}_{50}$. Furthermore, the bedload $\mathrm{D}_{16}$ 
415 was constantly coarser than the bulk mixture $\mathrm{D}_{16}$. We think this is explained by the smaller 416 amount of sand and granules in sediment 2 (Fig. 2), which mostly settled into the bed (a 417 mechanism known as kinetic sieving, Parker and Klingeman, 1982), leaving a small amount of 418 fines reaching the sediment trap.
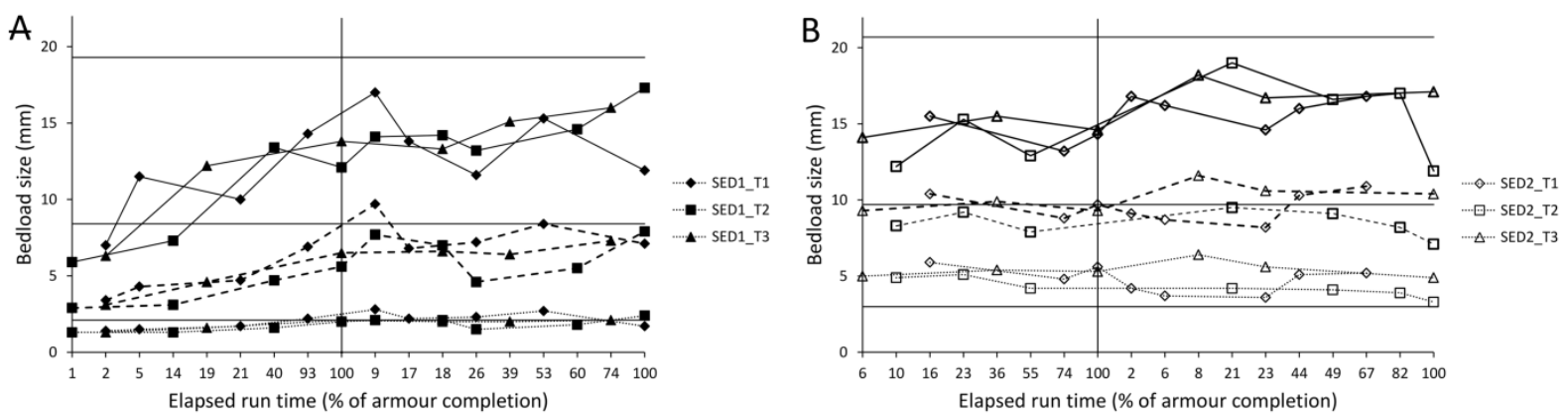

Fig. 4. Bedload composition throughout the development of the two successive armors for all replicated runs using (A) sediment 1; and (B) sediment 2. The elapsed run time was normalized by the time required for stable armor completion, with both $\mathrm{Q}_{1}$ and $\mathrm{Q}_{2}(100 \mathrm{~h}$ and $300 \mathrm{~h}$, respectively). Vertical lines separate armoring with $\mathrm{Q}_{1}$ and $\mathrm{Q}_{2}$. Continuous lines are for the bedload material $\mathrm{D}_{84}$, lines with large dash for $\mathrm{D}_{50}$, and lines with small dash for $\mathrm{D}_{16}$. Horizontal lines show the $\mathrm{D}_{16}, \mathrm{D}_{50}$ and $\mathrm{D}_{84}$ for the bulk mixtures (cf. Table 1).

\subsection{Armor composition and grain orientation}

427 Changes in surface texture are presented in Fig. 5. A marked change after $\mathrm{Q}_{1}$, with an increase 428 for all percentiles (i.e., $\mathrm{D}_{16}, \mathrm{D}_{50}$ and $\mathrm{D}_{84}$ ), indicates surface coarsening. Application of $\mathrm{Q}_{2}$ only impacted the coarse end of the GSD. The greater variability in the armor $\mathrm{D}_{84}$ (i.e., $\mathrm{D}_{84 \mathrm{~A}}$ ), compared to $\mathrm{D}_{16 \mathrm{~A}}$ and $\mathrm{D}_{50 \mathrm{~A}}$, likely relates to the preparation of the initial screeded beds and to

431 the availability of coarse particles being uncovered by the flow. As identified by the armor ratio 432 (defined as $\mathrm{D}_{50 \mathrm{~A}} / \mathrm{D}_{50}$ ), sediment 1 allowed the surface to armor more than the better-sorted 433 sediment 2 (mean armor ratio of 2.2 and 1.8 for sediment 1 and sediment 2, Fig. 5B). Analysis 434 of armor ratios for both sediment mixtures showed no significant differences between flow discharges, suggesting that the armors formed with $\mathrm{Q}_{1}$ persisted during $\mathrm{Q}_{2}$. 

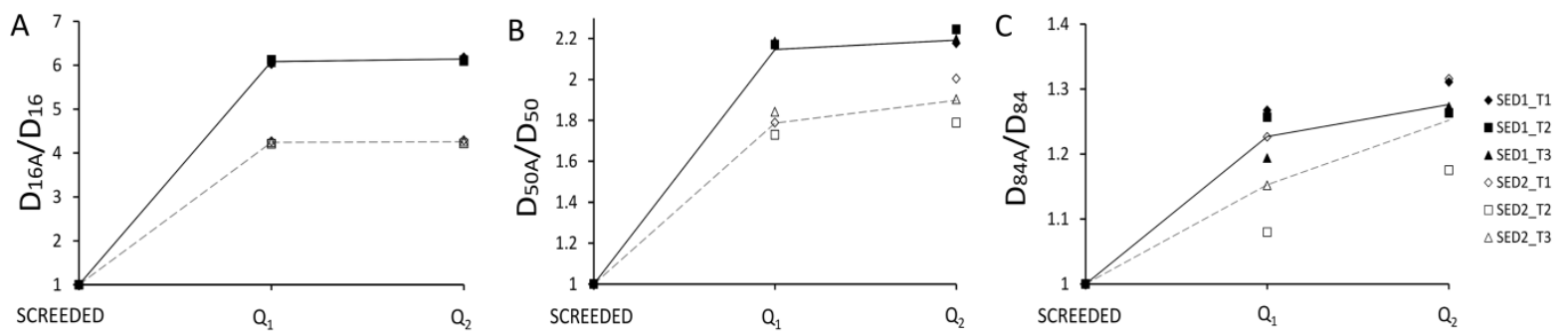

437 Fig. 5. Sediment bed-surface composition, in terms of (A) $D_{16},(B) D_{50}$ and (C) $D_{84}$, for the different

438 bed states (i.e., screeded, armored with $\mathrm{Q}_{1}$ and armored with $\mathrm{Q}_{2}$ ). Armor compositions obtained with

439 Basegrain ${ }^{\circledR}$ (associated with the subscript "A") were normalized by the bulk mixture characteristics

440 (cf. Table 1). The lines represent the average trends for each sediment mixture (continuous black lines

441 for sediment 1; dashed grey lines for sediment 2).

$442 \quad$ Figure 6 presents the preferential grain orientation on the armors determined using 443 automated image analysis. Because small grains in a mixture are generally more spherical than 444 large grains and lack directional preference (Rust, 1972; Richards and Clifford, 1991), the 445 trends presented essentially represent (but are not limited to) the coarse sediment fraction (i.e., $446 \mathrm{D}_{\mathrm{i}} \geq \mathrm{D}_{50}$ ). During $\mathrm{Q}_{1}$, the bed material preferentially aligned its long axis (i.e., a-axis) with the 447 flow direction, regardless of the sediment mixture (Figs. 6A and 6B). After $\mathrm{Q}_{2}$, the proportion 448 of armor grains perpendicular to the flow increased concurrently fewer grains aligned parallel 449 to the flow (Figs. 6D and 6E). A trend is observed between the bed-material size and the a-axis 450 orientation (Fig. 6F). Particularly for sediment 1, surface grains perpendicular to the flow after $451 \mathrm{Q}_{2}$ were (on average) coarser than the grains at rest parallel to the flow. 


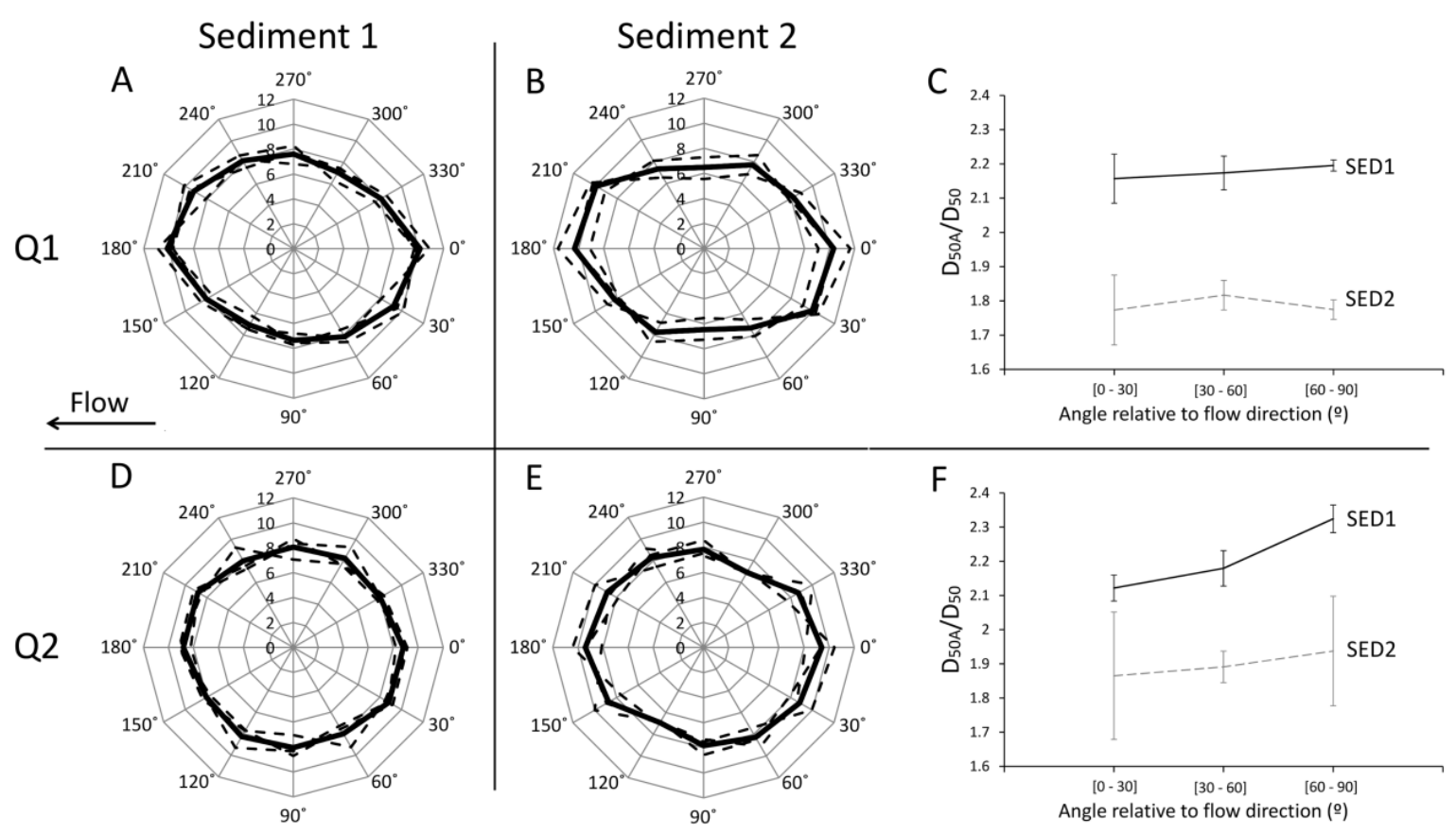

Fig. 6. Frequency distribution of bed-surface material (A, B, D, E) and normalized median sediment

454 size $(\mathrm{C}, \mathrm{F})$ for different a-axis (i.e., long axis) orientations, after armoring with $\mathrm{Q}_{1}(\mathrm{~A}, \mathrm{~B}, \mathrm{C})$ and $\mathrm{Q}_{2}(\mathrm{D}$,

455 E, F). The general tendency for each frequency distribution is presented as a thick continuous line,

456 which was obtained by averaging the results over the three replicated runs (dashed lines). The error bars

457 on the right have a length equal to two times the standard deviations, centered on the mean value.

\subsection{Bed-surface topography and structure}

459 Examples of the recorded bed topographies (i.e., DEMs) obtained during this study with digital 460 photogrammetry are presented in Fig. 7. As inferred from the screeded beds' DEMs (Figs. 7A and 7B), uniform surfaces were easier to replicate with sediment 1, due to the larger amount of

462 fines in the mixture and the accentuated compactness and sphericity of the grains (cf. Table 1).

463 Likewise visually, the two sediment mixtures responded differently to the imposed flows.

464 Sediment 1 arranged itself in more identifiable structures, such as reticulate stone cells (Church 465 et al., 1998; Hassan and Church, 2000), particle clusters (Heays et al., 2014) and small 466 transverse ribs. These structures formed essentially during armoring with $\mathrm{Q}_{2}$, when $\mathrm{Q}_{1}$ 467 produced more homogenous surfaces, with lesser particle grouping. Visible in Figs. 7C, D, G, 
$468 \mathrm{H}, \mathrm{K}$ and L, low-amplitude bedforms formed with water-work and increased in magnitude with

469 flow strength. These observations are repeated in section 4.1, where they are discussed in the $470 \quad$ light of other research.

\section{3.4. Bed-elevation distributions}

472 The analysis of bed-elevation moments (Fig. 8) reveals no differences between sediment 473 mixtures in terms of distribution skewness, but evidences significant differences for the range 474 and standard deviation. First, both sediment 1 and sediment 2, when screeded flat, were 475 characterized by a negative skewness. After armoring, the skewness became positive, which 476 agrees with previous findings that screeded beds are negatively skewed, in contrast to 477 positively-skewed water-worked beds (e.g., Nikora et al., 1998; Aberle and Nikora, 2006; 478 Cooper and Tait, 2009). Second, sediment 2 formed rougher surfaces for the two discharges, 479 indicated by a larger $\Delta_{Z}$ and $\sigma_{Z}$ compared with sediment 1 . Changing the flow discharge from $480 \mathrm{Q}_{1}$ to $\mathrm{Q}_{2}$ did not significantly impact $\mathrm{S}_{\mathrm{K}}$ and $\Delta_{\mathrm{Z}}$ values. Only $\sigma_{\mathrm{Z}}$ changed significantly between $481 \mathrm{Q}_{1}$ and $\mathrm{Q}_{2}$ water-working, for both sediment mixtures, indicating surface roughening with 482 discharge increases (e.g., Aberle and Nikora, 2006). 
Sediment 1
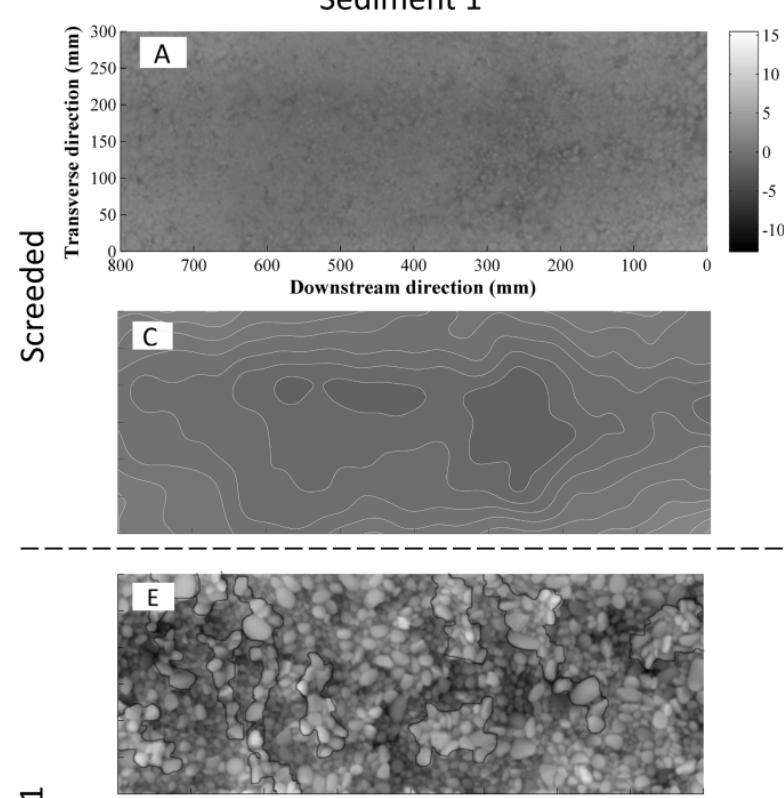

명
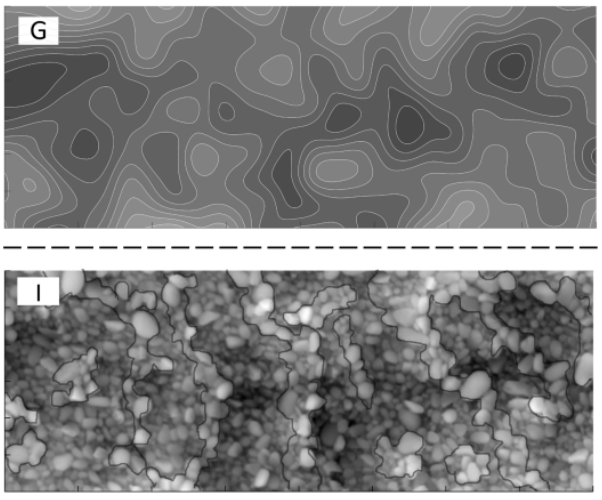

ชี

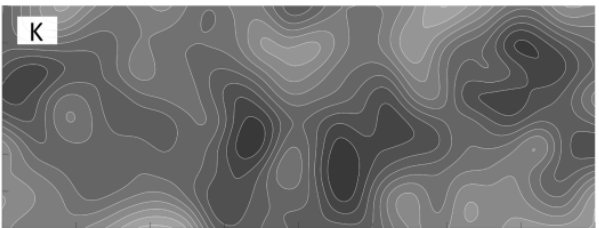

Sediment 2

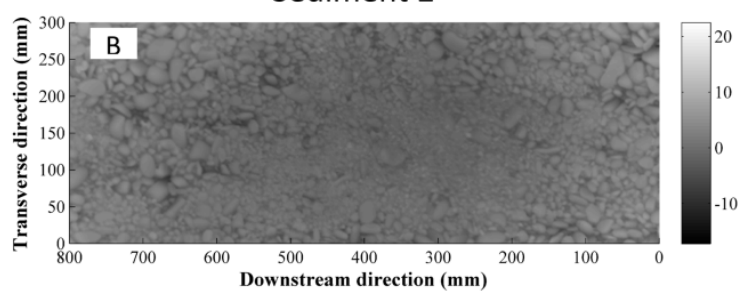

D
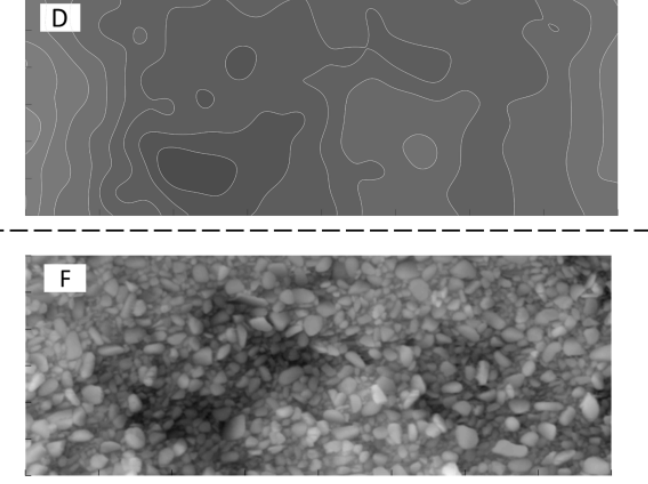

$\mathrm{H}$
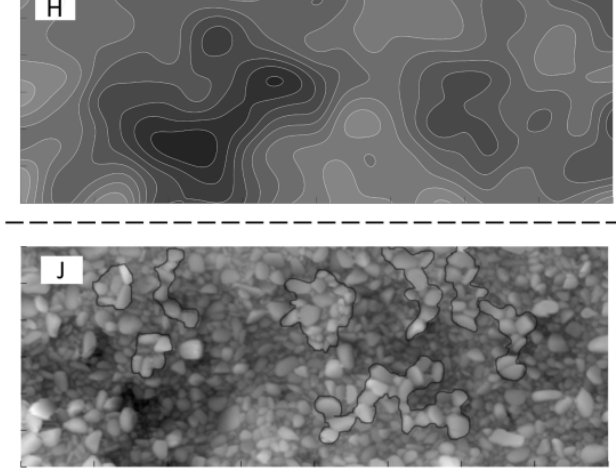

$\mathrm{L}$

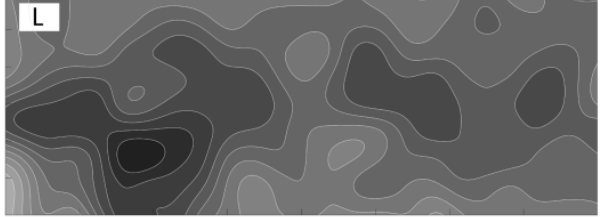

Fig. 7. DEMs of the sediment bed surface $\left(0.8 \times 0.3 \mathrm{~m}^{2}\right.$ with $1 \mathrm{~mm}$ sampling distance, linearly detrended (A, B, E, F, I, J)) and associated trend surfaces representing the bed undulations determined

486 through the application of a moving filter of radius $1.25 \mathrm{D}_{90 \mathrm{~A}}(\mathrm{C}, \mathrm{D}, \mathrm{G}, \mathrm{H}, \mathrm{K}, \mathrm{L})$, at the screeded stage 487 (A, B, C, D), after armoring with $\mathrm{Q}_{1}(\mathrm{E}, \mathrm{F}, \mathrm{G}, \mathrm{H})$, and after armoring with $\mathrm{Q}_{2}(\mathrm{I}, \mathrm{J}, \mathrm{K}, \mathrm{L})$. Only a single 488 run for each sediment mixture is presented, (A, C, E, G, I, K) SED1_T1; (B, D, F, H, J, L) SED2_T1. 489 The vertical scale is in millimeter, and is common for all DEMs made of the same sediment mixture. 490 Flow direction is from right to left. Grain structures described in Section 3.3 are tentatively highlighted. 

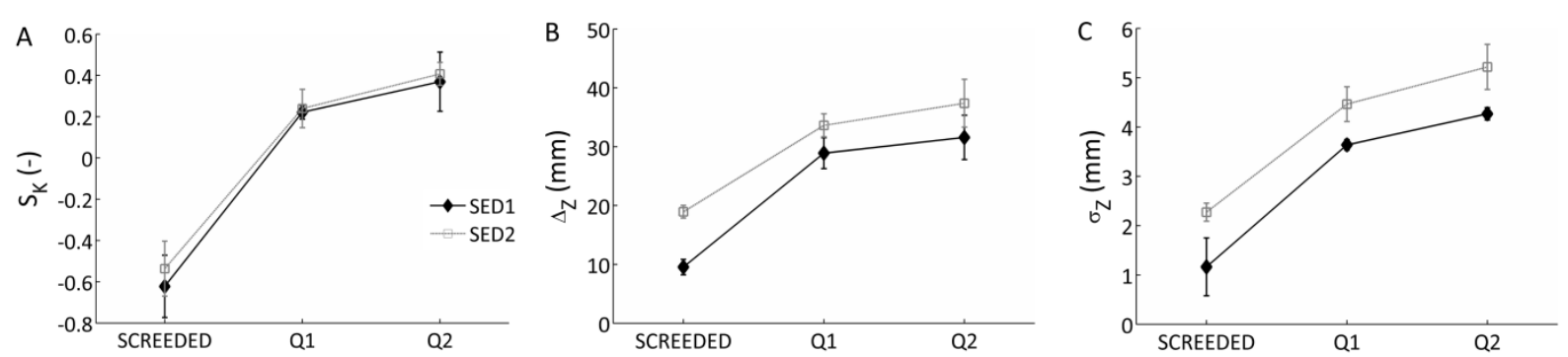

492 Fig. 8. First moments of detrended bed elevations for all replicated runs, represented by the distribution

493 (A) skewness $\left(\mathrm{S}_{\mathrm{K}}\right),(\mathrm{B})$ range $\left(\Delta_{\mathrm{Z}}\right)$ and $(\mathrm{C})$ standard deviation $\left(\sigma_{\mathrm{Z}}\right)$. The trend for each sediment mixture 494 is presented, which was obtained by averaging the results over the three replicated runs. The error bars 495 have a length equal to two times the standard deviations, centered on the mean value.

\subsection{Bed-elevation structure functions}

497 The analysis of second-order structure functions of bed elevations (Fig. 9) shows that despite

498 difficulties preparing the screeded beds identically at the beginning of each experimental run

499 (large fluctuations were explained by the random distribution of coarse particles at the surface

500 after manual preparation of the beds, Fig. 5C), the armors formed with $\mathrm{Q}_{1}$ and $\mathrm{Q}_{2}$ replicated well in terms of surface structure, in that the fluctuations between repeat runs were generally less after armoring. Sediment 1 and sediment 2 formed armors with identical complexities along the downstream direction (i.e., no significant differences in $\mathrm{H}_{\mathrm{X}}$ values). Likewise, scaling was isotropic for sediment 1 with $\mathrm{HX}_{\mathrm{X}}=\mathrm{H}_{\mathrm{Y}}$. For sediment 2, armors were more complex/irregular along the transverse direction, indicated by smaller $\mathrm{H}_{\mathrm{Y}}$ compared to $\mathrm{H}_{\mathrm{X}}$. Linked to this is the observation that sediment 1 formed transverse structures (Figs. 7E and 7I), which increased the spatial coherence (and therefore the regularity) between points along a same transect.

Also observed in Fig. 9, horizontal grain-roughness indices $\left(\Delta \mathrm{X}_{0}, \Delta \mathrm{Y}_{0}\right)$, taken separately, are identical between sediment 1 and sediment 2. Likewise, significance testing for both

511 mixtures shows that $\Delta \mathrm{X}_{0}$ was on average longer than $\Delta \mathrm{Y}_{0}$, and both indices increased with

512 discharge (e.g., Nikora et al., 1998; Ockelford and Haynes, 2013). 

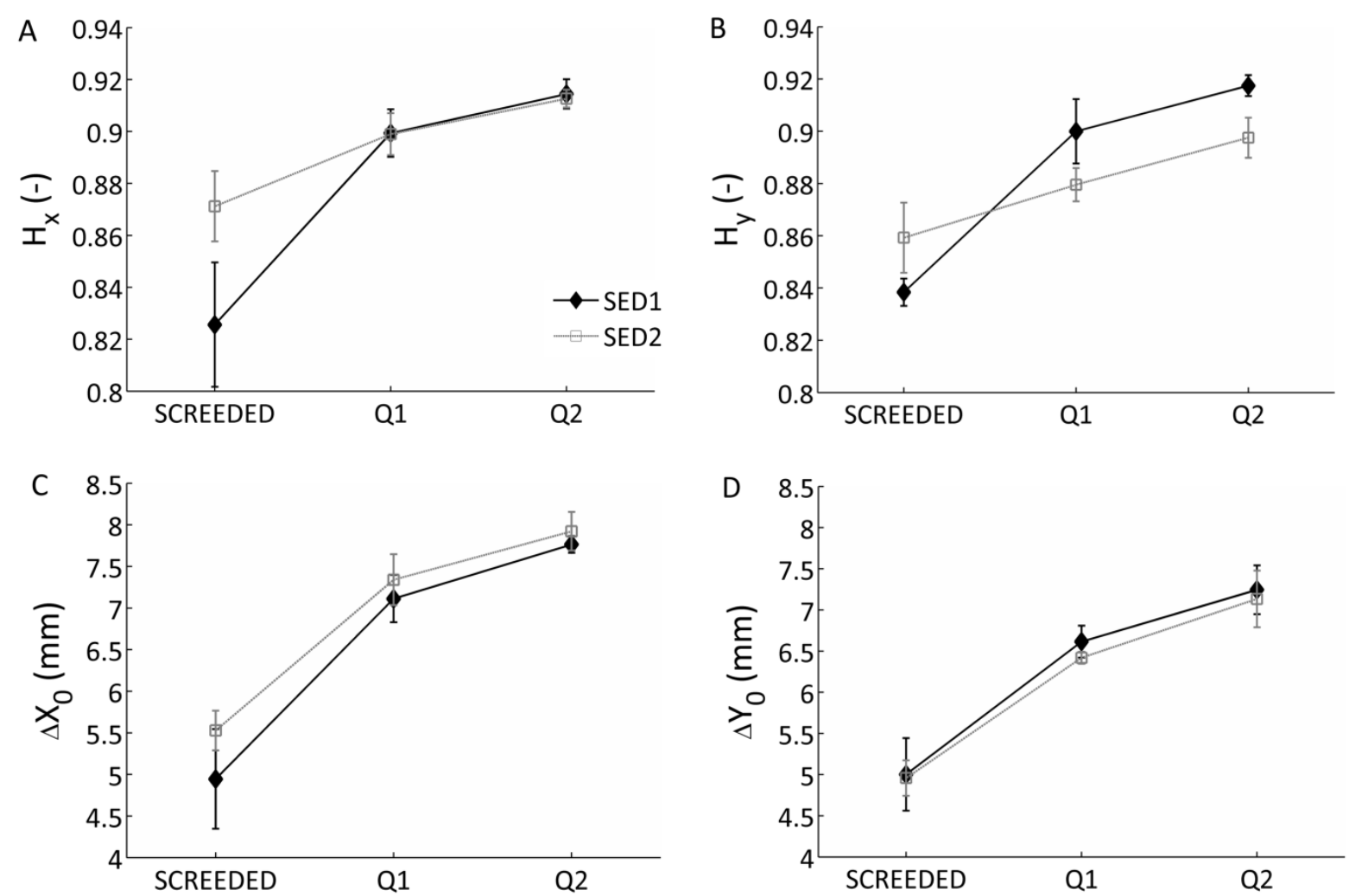

514 Fig. 9. Moments of detrended bed elevations determined from $2^{\text {nd }}$-order structure functions for all

515 replicated runs, represented by $(\mathrm{A}, \mathrm{B})$ the Hurst exponents $\left(\mathrm{H}_{\mathrm{X}}, \mathrm{H}_{\mathrm{Y}}\right)$ and $(\mathrm{C}, \mathrm{D})$ horizontal grain516 roughness indices $\left(\Delta \mathrm{X}_{0}, \Delta \mathrm{Y}_{0}\right)$ along $(\mathrm{A}, \mathrm{C})$ the downstream $(\mathrm{x})$ and $(\mathrm{B}, \mathrm{D})$ the transverse $(\mathrm{y})$ directions.

517 The trend for each sediment mixture is presented, which was obtained by averaging the results over the 518 three replicated runs. The error bars have a length equal to two times the standard deviations, centered 519 on the mean value.

\subsection{Surface slope and aspect}

521 The distributions of DEM cell slopes reinforce that the screeded beds made of sediment 1 and

522 sediment 2 differed substantially (Figs. 10A, 11A and 11B). For sediment 2, grains were often

523 not embedded in sand and small pebbles and were thus visible on the screeded surfaces (Fig.

524 7B), resulting in a larger range and more distributed cell slopes (Fig. 10A, Fig. 11B) compared

525 with sediment 1.

526 Despite differences at the screeded stage, water-working re-arranged sediment grains in a 527 consistent manner regardless of the sediment mixture (Figs. 10B and 10C). Armored surfaces 
were characterized by a larger range of slopes than the screeded surfaces, and increasing the flow discharge resulted in a distribution of slopes skewed further to the right.
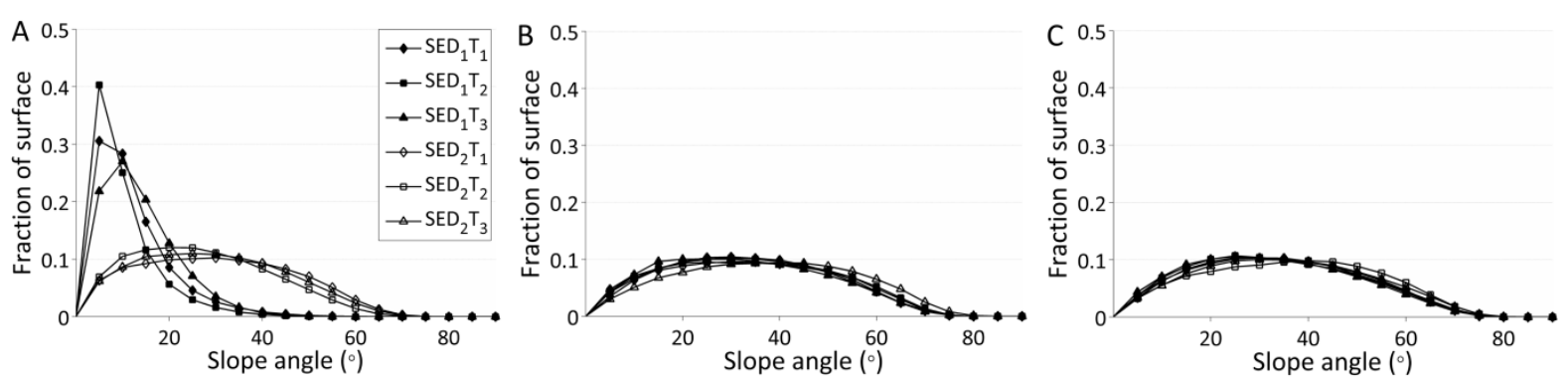

531 Fig. 10. Distribution of detrended DEM cell slope angles for (A) the screeded beds; (B) the beds armored with $\mathrm{Q}_{1}$; and $(\mathrm{C})$ the beds armored with $\mathrm{Q}_{2}$.

Figure 11 presents the combined distribution of DEM cell slope and aspect angles for the

534 surfaces presented in Fig. 7. A general tendency is observed, whereby the proportion of DEM 535 cells with upstream aspects (i.e., aspect angles around $0^{\circ}$ ) increases after armoring. 536 Nevertheless, sediment 1 formed armors with a greater number of grains sloping upstream compared to sediment 2, further accentuated after $\mathrm{Q}_{2}$ (Figs. 11E and 11F). This suggests that armors formed with sediment 1 presented accentuated grain imbrication compared to armors

539 formed with sediment 2, and grain imbrication became more prominent after $\mathrm{Q}_{2}$ (Hodge et al., 540 2009). From the dominant slope angles, the angle of imbrication is estimated at between $25^{\circ}$ 541 and $50^{\circ}$, which corresponds to imbrication angles also reported in Hodge et al. (2009). After $542 \mathrm{Q}_{1}$, sediment 2 formed surfaces with grains dipping mainly in a direction transverse to the flow

543 (Fig. 11D). Sediment 2 started to imbricate in a direction parallel to the flow with $\mathrm{Q}_{2}$, indicated 544 by the increasing proportion of cells with upstream aspects (Fig. 11F). 

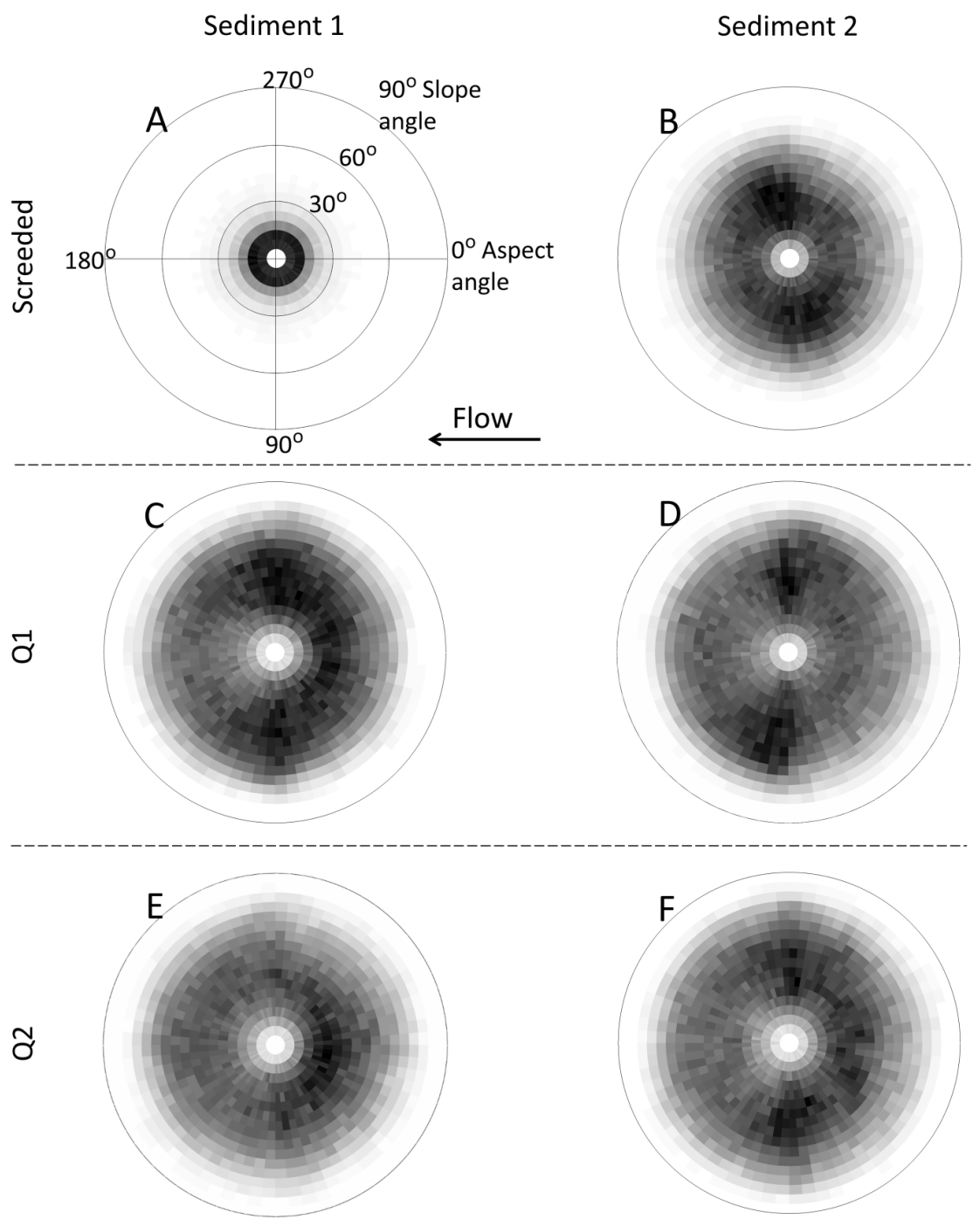

546 Fig. 11. Polar plots of all $1 \mathrm{~mm}^{2}$ detrended DEM grid cells aspect and slope angles, for the different

547 bed states: (A, B) screeded beds; (C, D) beds armored with $\mathrm{Q}_{1}$; and (E, F) beds armored with Q2. Only 548 a single run for each sediment mixture is presented, (A, C, E) SED1_T1; (B, D, F) SED2_T1. Aspect 549 angle is from 0 to $360^{\circ}$ and slope angle is from 0 to $90^{\circ}$; plots are shaded by point density (high density 550 in black, zero density in white). Flow direction is from $0^{\circ}$ to $180^{\circ}$.

\subsection{Inclination index}

552 Directional inclination indices collected for the run SED1_T1 (DEMs are presented in Fig. 7) 553 are presented in Fig. 12A. It shows that at the condition surface grains are imbricated (e.g., the 554 armor formed with $\mathrm{Q}_{2}$ ) plotting the directional inclination index is effective to determine the surface-forming flow direction (Millane et al., 2006). 
556

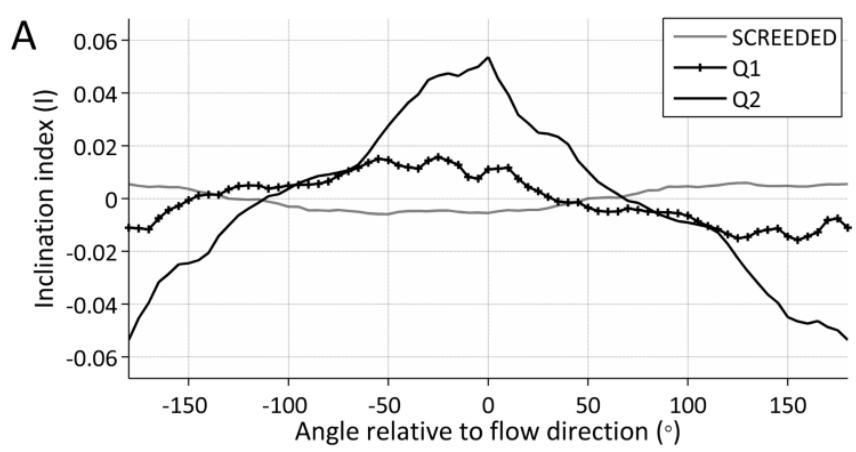

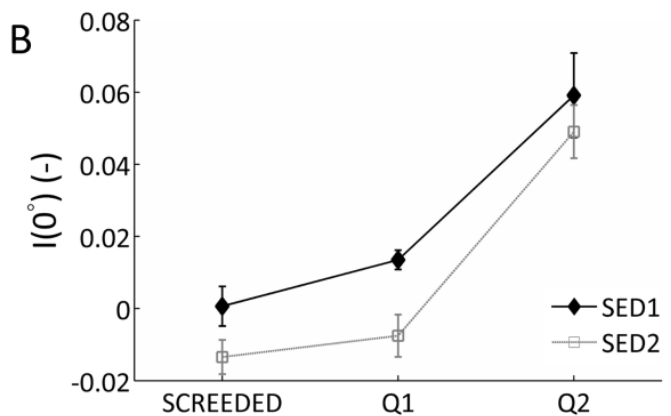

557 Fig. 12. (A) Directional inclination indices for the run SED1_T1 (DEMs are presented in Fig. 7).

558 Inclination was calculated for all angles between $-180^{\circ}$ and $180^{\circ}$ at a five-degree interval. (B)

559 Inclination index representing particle imbrication in a direction parallel to the flow $\left(\theta=0^{\circ}\right)$, for all

560 detrended DEMs. The trend for each sediment mixture is presented, which was obtained by averaging

561 the results over the three replicated runs. The error bars have a length equal to two times the standard

562 deviations, centered on the mean value.

563 All screeded beds measured in this study were characterized by a negative or near zero

$564 \mathrm{I}\left(0^{\circ}\right)$ (Fig. 12B), which means that the sediment was not imbricated in a direction parallel to

565 the flow. After $\mathrm{Q}_{1}$, only the beds made of sediment 1 started to imbricate, a conclusion already

566 supported by the analysis of DEM cell slope and aspect angles (Fig. 11C). However, the small

567 inclination index values $(\simeq 0.0175)$ suggest that imbrication was weak and limited to small

568 portions of the bed. $\mathrm{Q}_{2}$ was competent enough to imbricate particles for both sediment

569 mixtures. Imbrication was a priori more pronounced for sediment 1 , with $\mathrm{I}\left(0^{\circ}\right)$ equal to 0.06

570 and 0.05 on average for sediments 1 and 2, respectively, again echoing observations made on

571 Fig. 11, although statistically the difference between mixtures is not significant.

\section{3.8. Coefficient of variation}

573 This section examines if armors replicated experimentally under identical formative (i.e., flow

574 and sediment) conditions can be distinguished from each other, in order to test the replicability

575 of armor manifestations quantified using our dataset and methods. Table 3 compares the 
variability between replicated surfaces with the average spatial variability within these same

577 surfaces, using the percent coefficient of variation (CV). It shows that some DEM properties,

578 with large CV values, vary more than others. Particularly, bed-elevation skewness and the

579 inclination index are the parameters varying the most, both within and between surfaces, which

580 may partly indicate a larger sensitivity to measurements. Table 3 confirms our previous

581 observations that water-work forms (armored) surfaces more consistent, both spatially and

582 between repeat runs, with generally smaller CVs than screeded surfaces prepared manually.

583 Besides, we observe that the variability between replicated armors is comparable, if not lower

584 than the spatial variability within gravel beds, with 16 comparisons out of 27 possible showing

585 lower $\mathrm{CVs}$ between repeat runs compared to within DEMs. Thus, the variability between

586 replicated runs is in no way different from the variability naturally present within gravel-bed

587 surfaces, which is the expression of the stochastic processes at play (Piedra et al., 2012; Bertin

588 et al., 2017). Using the generic methods currently at hand therefore suggests that stable armors

589 replicated experimentally under identical flow and sediment conditions in this study cannot be

590 distinguished from each other. 
591 Table 3. Variability (using the percent coefficient of variation, CV) between and within replicated

592 surfaces. The variability within DEMs was measured using three DEM subsets of size $266 \times 300 \mathrm{~mm}^{2}$

593 and was averaged over the three replicated runs to provide the average spatial variability within gravel

594 beds of the same sediment and surface type.

\begin{tabular}{|c|c|c|c|c|c|c|c|c|c|}
\hline & & & $\mathrm{S}_{\mathrm{K}}$ & $\sigma_{\mathrm{Z}}$ & $\mathrm{Hx}_{\mathrm{X}}$ & $\mathrm{HY}_{\mathrm{Y}}$ & $\Delta \mathrm{X}_{0}$ & $\Delta Y_{0}$ & $\mathrm{I}\left(0^{\circ}\right)$ \\
\hline & Averaged & Screeded & $N . A$ & 12.7 & 2.0 & 1.5 & 3.5 & 2.5 & $N . A$ \\
\hline E & CV within & After $Q_{1}$ & 47.1 & 6.1 & 0.3 & 0.6 & 4.0 & 3.1 & 706 \\
\hline D & & & & & & & & & \\
\hline I & DEMs & After $\mathrm{Q}_{2}$ & 32.8 & 5.1 & 0.8 & 0.7 & 1.4 & 1.9 & 31.5 \\
\hline $\mathrm{E}$ & & Screeded & N.A & 16.1 & 2.9 & 0.6 & 12.1 & 8.8 & N.A \\
\hline $\mathrm{T}$ & & After $\mathrm{O}_{1}$ & 155 & 26 & 10 & 14 & 40 & 29 & 107 \\
\hline & repeat runs & & & & & & & & \\
\hline 1 & & After $Q_{2}$ & 38.8 & 4.0 & 0.6 & 0.4 & 1.3 & 4.1 & 19.8 \\
\hline $\mathrm{S}$ & Averaged & Screeded & N.A & 16.1 & 1.9 & 2.1 & 6.0 & 5.0 & N.A \\
\hline E & CV within & After $Q_{1}$ & 87.6 & 5.2 & 0.4 & 0.6 & 2.6 & 4.1 & N.A \\
\hline I & DEMs & After $Q_{2}$ & 16.6 & 6.7 & 0.5 & 0.6 & 2.5 & 4.1 & 71.3 \\
\hline $\begin{array}{l}\mathrm{E} \\
\mathrm{N}\end{array}$ & & Screeded & N.A & 13.1 & 1.6 & 1.6 & 4.3 & 4.3 & N.A \\
\hline $\mathrm{T}$ & & After $Q_{1}$ & 38.8 & 12.3 & 0.9 & 0.7 & 4.2 & 1.1 & N.A \\
\hline 2 & & After $Q_{2}$ & 13.6 & 1.2 & 0.4 & 0.9 & 2.9 & 4.8 & 15.0 \\
\hline
\end{tabular}

N.A stands for non-applicable, because of the existence of negative values, preventing the use of the coefficient of variation.

\section{Discussion}

\section{4.1. Stable armoring manifestations}

599 Stable fluvial armors formed in a laboratory flume have been analyzed using a range of

600 accepted statistical methods in order to identify the effects of surface texture and structure

601 during armoring and to test their replicability under identical flow and sediment conditions. 
602 The incorporation of multiple roughness parameters extended on previous studies, and enabled 603 a more holistic definition of armoring manifestations.

604 Our experimental setup offered important advantages over a conventional setup. A 605 vertically adjustable test section (cf. Fig. 1) allowed armor formation under consistent bed shear 606 stress, which was critical for studying replicability. This required that the sediment bed be 607 raised accordingly to the depth of erosion (cf. Chin et al., 1994). Measured bedload rates (Fig. 608 3) show the progressive transport reduction characteristic of stable armors (Proffitt, 1980; 609 Marion et al., 2003), and indicate consistency between the six runs $\left(\mathrm{R}^{2}=0.92\right.$ and 0.83 for $\mathrm{Q}_{1}$ 610 and $\mathrm{Q}_{2}$, respectively). This both justifies the used stopping criterion based on a pilot test and 611 verifies that the sediment recess was correctly adjusted, as otherwise major deviations would 612 be observed. We note that two phases in bedload temporal variation were identified in some 613 studies (e.g., Paris, 1992): a first phase generally short $\left(\sim 10^{2} \mathrm{~min}\right)$ with constant transport, and 614 a second phase showing the progressive bedload reduction. The bedload sampling frequency 615 in our experiment was not sufficient to identify the first phase.

616 In addition to bedload rate, the evolution of the bedload composition (Fig. 4) also was 617 consistent between replicated runs, showing partial transport necessary for stable armor 618 formation, and a predominantly finer and better-sorted bedload compared to the bulk mixture, 619 observations which are consistent with Proffitt's (1980) experiments. Conforming to flow 620 competence calculations using the Shields curve (Fig. 2B), we observed an increase in bedload 621 size during $\mathrm{Q}_{2}$, indicating coarser grains were transported compared to $\mathrm{Q}_{1}$, due to the increased 622 discharge.

623 Surface coarsening and the hiding of fines by bigger particles protruding into the flow are 624 other armoring manifestations we observed. Previous research suggests a specific armor 625 composition, dependent on the parent bed material and the formative discharge (e.g., Garde et 626 al., 2006). Accordingly, bed texture replicated well between repeat runs using the same 
sediment (with the $\mathrm{CV}$ for $\mathrm{D}_{16 \mathrm{~A}}, \mathrm{D}_{50 \mathrm{~A}}$ and $\mathrm{D}_{84 \mathrm{~A}}$ consistently below $5 \%$ ) but varied remarkably between the two mixtures (Fig. 5), with sediment 1 showing accentuated coarsening compared to sediment 2 . The latter can be explained by a greater entrainment propensity for sediment 1 (Fig. 2B), hence textural changes were accentuated and contrasted with sediment 2. Differences in sediment sorting between mixtures (cf. Table 1) may also be a reason, as well-sorted sediments were previously found to have smaller armor ratios than poorly-sorted sediments for a given bed shear stress (e.g., Proffitt, 1980; Gomez, 1994). Our experimental armor ratios (2.2 and 1.8 for sediment 1 and sediment 2, respectively) are in the range of values measured on stable armors in both the field (e.g., Hassan et al., 2006; Vericat et al., 2006) and the laboratory (e.g., Gomez, 1994; Curran and Waters, 2014). As an indication, an armor ratio of 2.0 has been cited as separating strong armoring from weak armoring (Hassan et al., 2006; Oldmeadow and Church, 2006). The observation that the armor ratio was virtually unchanged after $\mathrm{Q}_{2}$ (Fig. 5B) suggests that armors formed with $\mathrm{Q}_{1}$ did not break up in response to flow discharge increase, with the possible inference of constant roughness effects (e.g., Clifford et al., 1992; Wilcock and DeTemple, 2005).

Contrasting this observation, we observed that grains re-orientated during $\mathrm{Q}_{2}$, with increasing coarse grains aligned perpendicular to the flow (Fig. 6). This observation finds support in previous studies and is explained by the transport of coarse particles at low flows predominantly by rolling and sliding along the a-axis, perpendicular to the flow (e.g., Rust, 1972; Robert, 1991; Millane et al., 2006; Hodge et al., 2009). Q2 was more capable of moving the coarse sediment fraction in our experiments (Figs. 2B and 4), hence justifying the increased proportion of grains perpendicular to the flow after $\mathrm{Q}_{2}$. In comparison, $\mathrm{Q}_{1}$ was essentially capable of rotating large grains into more stable positions, which minimize drag (i.e., a-axis parallel to the flow), in conditions below the threshold for entrainment, as reported by others before (e.g., Butler et al., 2001; Aberle and Nikora, 2006). Likewise, previous research suggests 
that a grain orientation transverse to the flow provides the suitable framework for particle imbrication, since rolling and sliding gravels generally come to rest after contact with other particles with a dipping angle sloping upstream (e.g., Laronne and Carson, 1976; Hodge et al., 2009). More generally, our results emphasize that grain orientation cannot be used as an unambiguous indicator of flow direction (Rust, 1972; Hodge et al., 2009).

Also contrasting the observation that bed texture was virtually unchanged between $Q_{1}$ and $\mathrm{Q}_{2}$ (Fig. 5B), Fig. 8C shows that $\sigma_{\mathrm{Z}}$ (i.e., surface roughness) increased with armoring. Together with the observation of grain re-orientation (Fig. 6), this strengthens the argument that fluvial surfaces react to moderate changes in flow strength $\left(<10 \%\right.$ variation in $\overline{\mathrm{U}}$ and $\mathrm{u}^{*}$ between $\mathrm{Q}_{1}$ and $\mathrm{Q}_{2}$ ) through a variety of processes. This has implications for the examination of armor break-up during high flows, which is generally indicated by changing surface composition (Wilcock and DeTemple, 2005). Yager et al. (2015) recently asserted that comparing pre- and post-event data such as GSDs and armor ratios cannot determine if the original armor persisted intact. Our study now demonstrates the benefit of incorporating analyses of grain orientation and surface roughness.

Despite our finding that surface roughness is more responsive than surface composition to discharge increases, several workers previously suggested a relationship between $\sigma_{\mathrm{Z}}$ and sediment size (see Pearson et al., 2017 for a review). In this study, the fact that sediment 2 was coarser than sediment 1 (Fig. 2), certainly explains why armors made of sediment 2 were rougher (i.e., larger $\sigma_{z}$, Fig. $8 \mathrm{C}$ ). Sediment shape, whereby sediment 2 was more angular than sediment 1 (Table 1), provided the opportunity for particles to interlock more (Gomez, 1994), occasionally with gravels reposing on the side (Fig. 10), and therefore may also be responsible

674 for a greater surface roughness of the beds made with sediment 2 (Hodge et al., 2009). The 675 variable amounts of sand in the two mixtures (particle size $\leq 2 \mathrm{~mm}, 15 \%$ and $9 \%$ for sediment 6761 and sediment 2, respectively) may provide a further reason why sediment 2 formed rougher 
surfaces, since an increasing amount of sand reduces surface roughness (Curran and Waters, 2014).

Visualization of the DEMs (Fig. 7) suggests that grain structures and bed undulations are other armoring manifestations. In our tests, elongated structures, similar to the reticulate stone cells described by Church et al. (1998), formed essentially with sediment 1 during Q2 (i.e., for $\tau *=0.050$, cf. Table 2). Since this stabilizing mechanism was not evident in the armors formed with sediment 2 (i.e., for $\tau *=0.040$ and 0.046 for $\mathrm{Q}_{1}$ and $\mathrm{Q}_{2}$, respectively), this suggests that these structures develop once a certain transport capacity is exceeded. Elongated structures were also apparent in the flume experiments of Pender et al. (2001) for the highest discharges only. Back calculation of their experimental Shield stresses (assuming $\mathrm{D}_{50}=4.5 \mathrm{~mm}$ from their Fig. 1, and $\mathrm{S} . \mathrm{G}=2.6$ ) indicated that grain structures did not develop for $\tau *=0.045$, but formed as the discharge increased (i.e., for $\tau *=0.051$ ), which corroborates our findings with coarser sediment. We also observed the presence of low-amplitude bedforms on the armors, which formed with water-work and increased in magnitude and variability as discharge increased (Fig. 7). This was confirmed with a moving-window detrending technique that measured bed undulations larger than typical cluster size (Smart et al., 2002). Similar observations were recently presented, whereby bed undulations formed in tandem with grain-scale structures, and were tracked by changes in surface grain size (Powell et al., 2016; Bertin et al., 2017).

Results presented in Fig. 9 confirm that Hurst exponents are smaller (i.e., surface complexity is larger) for screeded beds, and increase with the flow discharge, as was observed in previous studies (e.g., Aberle and Nikora, 2006; Mao et al., 2011). This is because surfaces made of large individual particles (i.e., armored surfaces) create a less complex topography than surfaces constituting a large number of smaller particles, which is typical for screeded beds. This reduction of surface complexity after armoring is also apparent in Table 3, which shows a smaller spatial variability for armored beds, compared to screeded beds. Likewise, the 
702

703

704

705

706

707

708

709

710

711

712

713

714

715

716

717

718

719

720

721

722

723

724

725

726

increase in correlation lengths (Fig. 9) is explained by surface coarsening and the formation of grain structures occurring during armoring.

The analysis of DEM cell slopes shows that both grains' reposing angle and the amount of sediment grains coming at rest on the bed with a large dipping angle increased with armoring and transport capacity (Figs. 10 and 11). It is apparent that sediment shape also played a role in grains' reposing angle. Sediment 2, which was more angular than sediment 1 (Table 1), produced armors with more inclined and thus interlocked particles than sediment 1, which agrees with previous experimental results (Gomez, 1994).

The occurrence of imbricated grains after armoring is shown in Figs. 11 and 12. More particularly, it shows that armors formed with $\mathrm{Q}_{2}$ presented accentuated grain imbrication compared to the armors formed with the lower discharge $\mathrm{Q}_{1}$. When compared to our previous observations, whereby $\mathrm{Q}_{2}$ was more capable of moving coarse grains (Figs. 2B and 4), hence a greater number of gravels could be transported by rolling/sliding and deposited with the long axis transverse to the flow (Fig. 6C), this supports the argument that grain size and orientation on the armors, thus transport capacity, are important controls on grain imbrication (Rust, 1972).

Besides, Table 3 shows that increasing the flow discharge reduced the spatial variability for $\mathrm{I}\left(0^{\circ}\right)$ (at least for sediment 1$)$, giving further evidence that regions of grain imbrication extended during $\mathrm{Q}_{2}$.

Using our experimental results and comparisons with previous studies, it has been shown that gravel beds react to water-work through a variety of manifestations, for which bed composition and flow strength (hence transport capacity) are important controls. The fact that our observations confirm previous findings is important, as parameters influencing armor development are numerous, and their effects are generally evaluated using a single dataset. Out of the suite of analytical methods we used, stable armors formed with either sediment 1 or sediment 2 differed for all surface descriptors except preferential grain orientation (Fig. 6), 
bed-elevation skewness (Fig. 8A) and horizontal grain roughness indices $\Delta \mathrm{X}_{0}$ and $\Delta \mathrm{Y}_{0}($ Figs.

9C and 9D); whilst a change in formative discharge was evidenced by all descriptors but armor composition (Fig. 5), bed-elevation skewness (Fig. 8A) and vertical range (Fig. 8B). These experimental observations may well be useful for field investigations wanting to assess bed changes due to varying flow or sediment conditions. We showed that in spite of difficulties preparing the screeded beds identically at the beginning of each run, due to the random distribution of coarse particles near the surface after manual preparation of the beds, waterworking re-arranged the initially random sediment organization into pronounced patterns, such as grain grouping, interlocking and imbrication, which all contributed to an augmented surface consistency. We also demonstrated that the variability between experimentally-recreated armors does not differ from the natural spatial variability within gravel beds, which gives convincing evidence of armor structure replicability for a given formative discharge and parent bed material, something which had been assumed previously but not proven. When compared with previous studies on stable armor composition (e.g., Garde et al., 2006), our experimental results therefore suggest that gravel-beds' response (both textural and structural) is specific to the formative parameters. This verifies assumptions generally made in previous research, that applying the same flow to the same sediment produces a representative armored bed surface.

744 This consolidated knowledge is important for translating flume research to the real world, in particular as researchers are now looking at the relationships between armor parameters and formative conditions, which could allow determination of antecedent flow conditions from DEM analysis and prediction of bed response to future flows.

\subsection{Experimental constraints and practical applications}

749 Research on fluvial armors previously made use of experimental facilities as these can offer 750 considerable advantages over a field setup. With simplified channel form geometries, steady and uniform flow conditions, and improved measurement capabilities, all common attributes 
752 of flume studies, fluvial processes that may go unnoticed in the field can sometimes be revealed experimentally.

In this study, the cross-sectional channel form was constant and rectangular, the bed shear stress was constant throughout armor formation, roughness was limited to the effect of grain and low-amplitude bedforms on the bed, and no sediment originated from upstream. This enabled quantification of the effects of flow strength and bed composition onto the resulting armors, without the influence of a real hydrograph and sediment supply.

The effects of unsteady flows and upstream sediment supply were recently investigated by others (e.g., Mao et al., 2011; Mao, 2012; Powell et al., 2016). Interestingly, Powell et al. (2016) reported that armoring manifestations occurred in a relatively short time (a few hours), after which bed adjustment was minimal. This suggests that the bed conditions measured at the time of armor completion in our experiments may also be representative of the earlier stages of armor development. Hence, armors observed in the field, although formed over shorter timeframes, may reach the same statistical properties (i.e., equilibrium) as armors formed in laboratory flumes. Another interesting aspect raised by Powell et al. (2016) is the question of how much sediment supply reduction from upstream will cause a shift from mobile to static armor conditions. Future experimental work could try to answer this question, as this may also be helpful to improve bedload transport predictions for the field.

Our finding that gravel-beds' response is specific to the formative parameters suggests that armoring manifestations can be parameterized beyond a simple percentile of bed material GSD, and the bed properties can be linked to the formative parameters. To strengthen this argument and to provide a broader context for our findings, we combined our experimental results with those presented in Aberle and Nikora (2006), Cooper et al. (2008), Cooper and Tait (2009), Mao et al. (2011), Pledger et al. (2014), Powell et al. (2016) and Qin et al. (2013), representing the addition of 41 gravel armors (of which 18 are mobile armors formed in conditions of 
sediment feeding (Cooper and Tait, 2009; Pledger et al., 2014) or sediment recirculation (Mao et al., 2011; Powell et al., 2016)). This extended the range of bulk sediment $\left(\mathrm{D}_{50}=[4.0-13.2]\right.$ $\mathrm{mm})$ and formative Shields stress $\left(\tau_{*}=[0.023-0.102]\right)$, allowing extending the analysis of the effects of flow strength and bed composition on the armor properties.

The extended dataset presented in Fig. 13A confirms the strong link between bed composition and surface roughness $\left(\mathrm{R}^{2}=0.83\right.$ between $\mathrm{D}_{84 \mathrm{~A}}$ and $\left.\sigma_{\mathrm{Z}}\right)$. Because of the strong relationship, some suggested the interchangeable use of $\sigma_{Z}$ and grain-size percentiles as indicators of surface roughness. However, and as observed in this study, armor topography is more sensitive to changes in discharge than armor composition, and shows a better relationship with the Shields (or shear) stress than $\mathrm{D}_{84 \mathrm{~A}}\left(\mathrm{R}^{2}=0.64\right.$ compared to $\mathrm{R}^{2}=0.47$, Figs. $13 \mathrm{~B}$ and $13 \mathrm{C})$. Figures $13 \mathrm{~B}, 13 \mathrm{D}$ and $13 \mathrm{E}$ show how the armor $\sigma_{\mathrm{Z}}, \mathrm{S}_{\mathrm{K}}$ and $\mathrm{I}\left(0^{\circ}\right)$ increase with Shields stress, demonstrating previous assumptions of a strong control of flow strength on bed structure (e.g., Aberle and Nikora, 2006; Mao et al., 2011). Figure 13E shows that streamwise particle imbrication increases with transport capacity. It was hypothesized in the past that imbrication forms as a result of the entrainment of the coarse sediment fraction in a mixture (Rust, 1972).

To explain some of the scatter in Fig. 13, it is important to realize the different conditions under which each dataset was obtained. The scatter could certainly be reduced if consistent DEM analysis was applied across studies. For instance, the decision on the detrending method used will impact results (Bertin et al., 2017). In this study, low amplitude bedforms were filtered during detrending, and DEM properties were related to the grain topography. However, other studies reported removing a linear trend only (e.g., Aberle and Nikora, 2006). Likewise, we showed that DEM size is an important parameter to consider, as some structural properties (especially grain imbrication and elevation skewness) vary largely within a patch (Table 3). Hence, a recommendation on a suitable DEM size, allowing robust measures to be obtained with little effect due to surface spatial variability, would benefit comparisons between studies. 
802 Finally, the combined dataset includes results obtained from both stable and mobile armors,

803 despite previous work suggested structural differences between the two (Mao et al., 2011).

804 Here, the relationships were not affected by limiting the analysis to stable or mobile armors.

805 Now that the random-field approach has become fairly common as a way to characterize

806 roughness, with increasing applications in the field (e.g., Hodge et al., 2009; Hodge et al., 2013;

807 Bertin and Friedrich, 2016), it is expected that further work on fluvial armors and their

808 formative controls will extend the range of flow and sediment conditions presented in Fig. 13,

809 and will ultimately examine the possibility to scale experimental results to field situations.
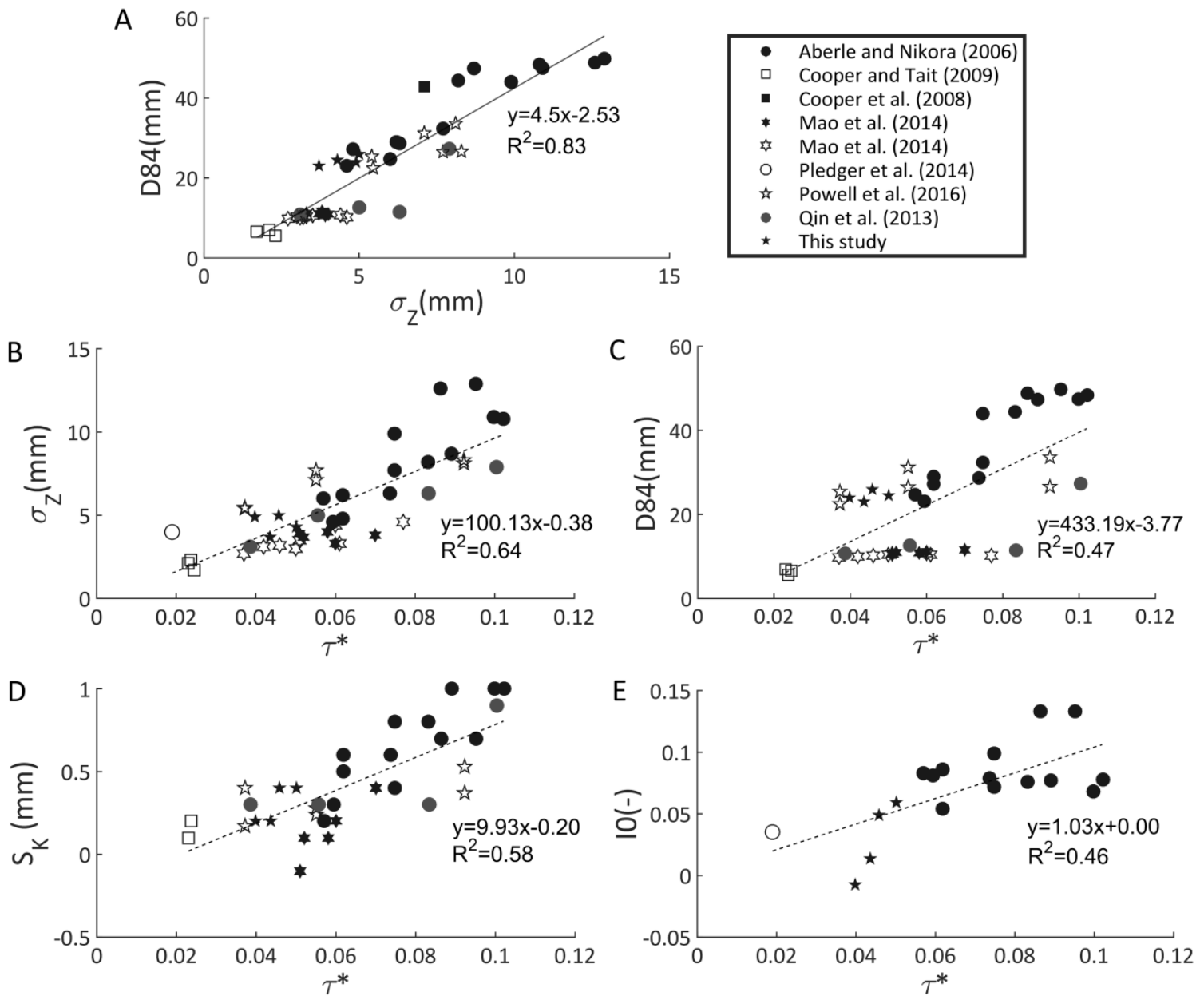

810

811 Fig. 13. Comparison with published flume data on streambed armoring. (A) Relationship between

812 armor composition (represented by $\mathrm{D}_{84 \mathrm{~A}}$ ) and armor topography (represented by $\sigma_{\mathrm{Z}}$ ). Other subplots are

813 structural properties against Shields stress (i.e., shear stress normalized by $\mathrm{D}_{50}$ ): (B) standard deviation 
814 of bed elevations, (C) armor $\mathrm{D}_{84}$, (D) skewness and (E) inclination index representing particle

815 imbrication in the flow direction. Open markers correspond to mobile armors. In the case data was not

816 collated in tables, it was digitized from graphs with the best care possible. Depending on the data source,

817 the Shields stress had to be re-calculated from the shear stress and the bulk mixture $\mathrm{D}_{50}$. Dashed lines

818 are the functional lines best representing the data (Mark and Church, 1977).

\section{5. Conclusions}

820 In this study, we designed laboratory experiments to recreate stable armoring, a natural 821 phenomenon occurring in poorly-sorted gravel-bed rivers. The use of photogrammetric techniques enabled a detailed characterization of gravel-bed surfaces and their adjustments to competent flows in replicated experimental runs. The study was performed under conditions

824 of sediment starvation and partial transport, with the aim of determining if stable armor 825 properties, especially structural, are replicable under identical formative conditions. We presented efficient and effective bed-surface measurements, whereby texture and structure were accurately estimated through water and obviated the need to drain and refill the flume inbetween measurements.

Our analyses identified differences between stable armors formed under identical flow conditions but different sediment mixtures. Change detection in the armor properties, when the

831 formative discharge was increased moderately, was also possible. We found that bed topography (structure) was more responsive to changes in flow strength and displayed more degrees of adaptability than texture alone.

834 Our experimental results support the concept of replicability in stable armor properties 835 under identical flow and sediment conditions, despite difficulties manually replicating the screeded beds at the start of each run. This suggests that in conditions of parallel degradation,

837 gravel-beds' response to water-work is specific to the formative parameters, even though the 838 inherent mechanisms for the armor layer formation are stochastic. Comparison of our data with 
other flume data on streambed armoring illustrated the relationships between armor structure and both Shields stress and parent bed composition.

Analysis of fluvial surface structure using DEMs shows great promise for progress on roughness characterization based on topography and effective parameterization in sediment

843 transport and flow resistance equations. Further work is necessary to determine the temporal scales at which fluvial surfaces relate to the forming flow rate. In this study, stable armors were given the time to develop extensively, although this process varies in nature. Finally, a different flow and sediment conditions is needed to parameterize bed roughness and link it to

848 flow processes.

849

850

\section{Acknowledgments}

The study was partly funded by the Marsden Fund (Grant No. UOA1412) administered by the Royal Society of New Zealand. The authors would like to thank M. Dequidt and S. Stähly for their assistance during the experimental programme and J. Groom for her comments on the manuscript. Reviews by Michael Church, John Buffington, the editor of Geomorphology: Scott A. Lecce and anonymous reviewers are gratefully acknowledged.

\section{References}

Aberle, J., Nikora, V., 2006. Statistical properties of armored gravel bed surfaces. Water Resour. Res. 42(11), W11414.

Bergeron, N., 1996. Scale-space analysis of stream-bed roughness in coarse gravel-bed streams. Math. Geol. 28(5), 537-561.

Bertin, S., Friedrich, H., 2014. Measurement of gravel-bed topography: evaluation study applying statistical roughness analysis. J. Hydraul. Eng. 140(3), 269-279.

Bertin, S., Friedrich, H., 2016. Field application of close-range digital photogrammetry (CRDP) for grainscale fluvial morphology studies. Earth Surf. Process. Landf. 41, 1358-1369.

Bertin, S., Friedrich, H., Delmas, P., Chan, E., Gimel'farb, G., 2015. Digital stereo photogrammetry for grain-scale monitoring of fluvial surfaces: Error evaluation and workflow optimisation. ISPRS J. Photogramm. Remote Sens. 101(0), 193-208. 
Bertin, S., Groom, J., Friedrich, H., 2017. Isolating roughness scales of gravel-bed patches. Water Resour. Res. 53(8), 6841-6856.

Butler, J.B., Lane, S.N., Chandler, J.H., 2001. Characterization of the structure of river-bed gravels using two-dimensional fractal analysis. Math. Geol. 33(3), 301-330.

Chin, C., Melville, B., Raudkivi, A., 1994. Streambed Armoring. J. Hydraul. Eng. 120(8), 899-918.

Church, M.A., McLean, D.G., Wolcott, J.F., 1987. River bed gravel: sampling and analysis. Sediment Transport in Gravel-bed River. Wiley, Chichester.

Church, M., Hassan, M.A., Wolcott, J.F., 1998. Stabilizing self-organized structures in gravel-bed stream channels: Field and experimental observations. Water Resour. Res. 34(11), 3169-3179.

Clayton, J.A., Pitlick, J., 2008. Persistence of the surface texture of a gravel-bed river during a large flood. Earth Surf. Process. Landf. 33(5), 661-673.

Clifford, N., Robert, A., Richards, K., 1992. Estimation of flow resistance in gravel-bedded rivers a physical explanation of the multiplier of roughness length. Earth Surf. Process. Landf. 17(2), 111-126.

Coleman, S.E., Nikora, V.I., Aberle, J., 2011. Interpretation of alluvial beds through bed-elevation distribution moments. Water Resour. Res. 47(11), W11505.

Cooper, J.R., Aberle, J., Koll, K., McLelland, S.J., Murphy, B.J., Tait, S., Marion, A., 2008. Observation of the near-bed flow field over gravel bed sur-faces with different roughness length scales. In: M.A.K. M. Altinakar, Aydin, I., Cokgor, S., and S. Kirkgoz, Kubaba (Ed.), RiverFlow 2008, Cesme, Turkey, pp. 739-746.

Cooper, J.R., Tait, S.J., 2009. Water-worked gravel beds in laboratory flumes - a natural analogue? Earth Surf. Process. Landf. 34(3), 384-397.

Curran, J., Tan, L., 2014. Effect of Bed Sand Content on the Turbulent Flows Associated with Clusters on an Armored Gravel Bed Surface. J. Hydraul. Eng. 140(2), 137-148.

Curran, J.C., Waters, K.A., 2014. The importance of bed sediment sand content for the structure of a static armor layer in a gravel bed river. J. Geophys. Res. Earth Surf. 119(7), 1484-1497.

Detert, M., Weitbrecht, V., 2012. Automatic object detection to analyze the geometry of gravel grains. In: M. (Ed.) (Ed.), RiverFlow 2012. Taylor and Francis Group, San Jose, Costa Rica, pp. 595-600.

Fehr, R., 1987. Geschiebeanalysen in Gebirgsflüssen translated Analysis of Sedimentary Bed Material in Mountain Rivers. Conversion and Comparison of Various Analytical Methods. Mitteilungen derVersuchsanstalt fürWasserbau, Hydrologie und Glaziologie, Eidgenössische Technische Hochschule, Zürich, Nr. 92, 1987.

Folk, R.L., Ward, W.C., 1957. Brazos River bar [Texas]; a study in the significance of grain size parameters. J. Sediment. Res. 27(1), 3-26.

Garde, R.J., Sahay, A., Bhatnagar, S., 2006. A simple mathematical model to predict the particle size distribution of the armour layer. J. Hydraul. Res. 44(6), 815-821.

Gessler, J., 1967. The beginning of bedload movement of mixtures investigated as natural armoring in channels. W.M. Keck Laboratory of Hydraulics and Water Resources, California Institute of Technology, Pasadena, Calif.

Gimel'farb, G., 2002. Probabilistic regularisation and symmetry in binocular dynamic programming stereo. Pattern Recogn. Lett. 23(4), 431-442.

Gomez, B., 1983. Temporal variations in bedload transport rates: The effect of progressive bed armouring. Earth Surf. Process. Landf. 8(1), 41-54.

Gomez, B., 1993. Roughness of stable, armored gravel beds. Water Resour. Res. 29(11), 3631-3642.

Gomez, B., 1994. Effects of particle shape and mobility on stable armor development. Water Resour. Res. 30(7), 2229-2239.

Haschenburger, J.K., Wilcock, P.R., 2003. Partial transport in a natural gravel bed channel. Water Resour. Res. 39(1), 1020.

Hassan, M.A., Church, M., 2000. Experiments on surface structure and partial sediment transport on a gravel bed. Water Resour. Res. 36(7), 1885-1895. 
Hassan, M.A., Egozi, R., Parker, G., 2006. Experiments on the effect of hydrograph characteristics on vertical grain sorting in gravel bed rivers. Water Resour. Res. 42(9).

Heays, K., 2012. Cluster formation and stream-bed armouring a photogrammetric study. PhD PhD thesis, The University of Auckland, Auckland, $292 \mathrm{pp}$.

Heays, K.G., Friedrich, H., Melville, B.W., 2014. Laboratory study of gravel-bed cluster formation and disintegration. Water Resour. Res. 50(3), 2227-2241.

Hodge, R., Brasington, J., Richards, K., 2009. Analysing laser scanned digital terrain models of gravel bed surfaces: linking morphology to sediment transport processes and hydraulics. Sedimentology 56(7), 2024-2043.

Hodge, R.A., Sear, D.A., Leyland, J., 2013. Spatial variations in surface sediment structure in riffle-pool sequences: a preliminary test of the Differential Sediment Entrainment Hypothesis (DSEH). Earth Surf. Process. Landf. 38(5), 449-465.

Krumbein, W.C., 1941. Measurement and geological significance of shape and roundness of sedimentary particles. J. Sediment Petrol. 11, 64-72.

Lane, S.N., 2005. Roughness - time for a re-evaluation? Earth Surf. Process. Landf. 30(2), 251-253.

Laronne, J.B., Carson, M.A., 1976. Interrelationships between bed morphology and bed-material transport for a small, gravel-bed channel. Sedimentology 23(1), 67-85.

Mao, L., 2012. The effect of hydrographs on bed load transport and bed sediment spatial arrangement. J. Geophys. Res. Earth Surf. 117(F3).

Mao, L., Cooper, J.R., Frostick, L.E., 2011. Grain size and topographical differences between static and mobile armour layers. Earth Surf. Process. Landf. 36(10), 1321-1334.

Marion, A., Tait, S.J., McEwan, I.K., 2003. Analysis of small-scale gravel bed topography during armoring. Water Resour. Res. 39(12), 11 pp.

Mark, D.M., Church, M., 1977. On the misuse of regression in earth science. Math. Geol. 9(1), 63-75.

Millane, R.P., Weir, M.I., Smart, G.M., 2006. Automated Analysis of Imbrication and Flow Direction in Alluvial Sediments Using Laser-Scan Data. J. Sediment. Res. 76(8), 1049-1055.

Nikora, V.I., Goring, D.G., Biggs, B.J.F., 1998. On gravel-bed roughness characterization. Water Resour. Res. 34(3), 517-527.

Ockelford, A.-M., Haynes, H., 2013. The impact of stress history on bed structure. Earth Surf. Process. Landf. 38(7), 717-727.

Odgaard, A.J., 1984. Grain size distribution of riverbed armor layers. J. Hydraul. Eng. 110(10), 14791484.

Oldmeadow, D.F., Church, M., 2006. A field experiment on streambed stabilization by gravel structures. Geomorphology 78(3-4), 335-350.

Paris, E., 1992. Time-space bed load evolution in static armour formation, Grain sorting seminar. Eidgenössische Technische Hochschule Zürich, Switzerland, Ascona, Switzerland, pp. 193-206.

Parker, G., Klingeman, P.C., 1982. On why gravel bed streams are paved. Water Resour. Res. 18(5), 1409-1423.

Parker, G., Sutherland, A.J., 1990. Fluvial armor. J. Hydraul. Res. 28(5), 529-544.

Pearson, E., Smith, M.W., Klaar, M.J., Brown, L.E., 2017. Can high resolution 3D topographic surveys provide reliable grain size estimates in gravel bed rivers? Geomorphology 293, Part A, 143155.

Pender, G., Hoey, T.B., Fuller, C., McEwan, I.K., 2001. Selective bedload transport during the degradation of a well sorted graded sediment bed. J. Hydraul. Res. 39(3), 269-277.

Piedra, M.M., Haynes, H., Hoey, T.B., 2012. The spatial distribution of coarse surface grains and the stability of gravel river beds. Sedimentology 59(3), 1014-1029.

Pitlick, J., Mueller, E.R., Segura, C., Cress, R., Torizzo, M., 2008. Relation between flow, surface-layer armoring and sediment transport in gravel-bed rivers. Earth Surf. Process. Landf. 33(8), 11921209. 
Pledger, A.G., Rice, S.P., Millett, J., 2014. Reduced bed material stability and increased bedload transport caused by foraging fish: a flume study with juvenile Barbel (Barbus barbus). Earth Surf. Process. Landf. 39(11), 1500-1513.

Powell, D.M., Ockelford, A., Rice, S.P., Hillier, J.K., Nguyen, T., Reid, I., Tate, N.J., Ackerley, D., 2016. Structural properties of mobile armors formed at different flow strengths in gravel-bed rivers. J. Geophys. Res. Earth Surf.

Proffitt, G.T., 1980. Selective transport and armouring of non-uniform alluvial sediments. PhD, University of Canterbury, Christchurch, 203 pp.

Qin, J., Zhong, D., Wang, G., Ng, S.L., 2012. On characterization of the imbrication of armored gravel surfaces. Geomorphology 159-160, 116-124.

Qin, J., Zhong, D., Wang, G., Ng, S.L., 2013. Influence of particle shape on surface roughness: Dissimilar morphological structures formed by man-made and natural gravels. Geomorphology 190(0), 16-26.

Richards, K., Clifford, N., 1991. Fluvial geomorphology: structured beds in gravelly rivers. Prog. in Phys. Geogr. 15(4), 407-422.

Robert, A., 1991. Fractal properties of simulated bed profiles in coarse-grained channels. Math. Geol. 23(3), 367-382.

Robert, A., Richards, K.S., 1988. On the modelling of sand bedforms using the semivariogram. Earth Surf. Process. Landf. 13(5), 459-473.

Rust, B.R., 1972. Pebble orientation in fluvial sediments. J. Sediment Petrol., 42(2), 384-388.

Smart, G., Duncan, M., Walsh, J., 2002. Relatively rough flow resistance equations. J. Hydraul. Eng. 128(6), 568-578.

Spiller, S., Rüther, N., Baumann, B., 2012. Artificial reproduction of the surface structure in a gravel bed, 2nd IAHR Europe Congress, TU München, Germany.

Vericat, D., Batalla, R.J., Garcia, C., 2006. Breakup and reestablishment of the armour layer in a large gravel-bed river below dams: The lower Ebro. Geomorphology 76(1-2), 122-136.

Wilcock, P.R., DeTemple, B.T., 2005. Persistence of armor layers in gravel-bed streams. Geophys. Res. Lett. 32(8), L08402.

Willets, B.B., Maizels, J.K., Florence, J., 1988. The simulation of streambed armouring and its consequences. Proceedings of the Institution of Civil Engineers 84(3), 615-617.

Yager, E.M., Kenworthy, M., Monsalve, A., 2015. Taking the river inside: Fundamental advances from laboratory experiments in measuring and understanding bedload transport processes. Geomorphology 244, 21-32. 